\title{
Low-cost production and application of lipopeptide for bioremediation and plant growth by Bacillus subtilis SNW3
}

Aiman Umar ${ }^{1}$, Aneeqa Zafar ${ }^{1}$, Hasina Wali ${ }^{1,2}$, Meh Para Siddique ${ }^{4}$, Muneer Ahmed Qazi 1,3, Afshan Hina Naeem', Zulfiqar Ali Malik ${ }^{3}$ and Safia Ahmed ${ }^{1 *}$ (1)

\begin{abstract}
At present time, every nation is absolutely concern about increasing agricultural production and bioremediation of petroleum-contaminated soil. Hence, with this intention in the current study potent natural surfactants characterized as lipopeptides were evaluated for low-cost production by Bacillus subtilis SNW3, previously isolated from the Fimkessar oil field, Chakwal Pakistan. The significant results were obtained by using substrates in combination (white beans powder $(6 \% \mathrm{w} / \mathrm{v})+$ waste frying oil $(1.5 \% \mathrm{w} / \mathrm{v})$ and $(0.1 \% \mathrm{w} / \mathrm{v})$ urea) with lipopeptides yield of about $1.17 \mathrm{~g} / \mathrm{L}$ contributing $99 \%$ reduction in cost required for medium preparation. To the best of our knowledge, no single report is presently describing lipopeptide production by Bacillus subtilis using white beans powder as a culture medium. Additionally, produced lipopeptides display great physicochemical properties of surface tension reduction value $(\mathrm{SFT}=28.8 \mathrm{mN} / \mathrm{m})$, significant oil displacement activity $(\mathrm{ODA}=4.9 \mathrm{~cm})$, excessive emulsification ability $(E 24=69.8 \%)$, and attains critical micelle concentration (CMC) value at $0.58 \mathrm{mg} / \mathrm{mL}$. Furthermore, biosurfactants produced exhibit excellent stability over an extensive range of $\mathrm{pH}(1-11)$, salinity $(1-8 \%)$, temperature $\left(20-121^{\circ} \mathrm{C}\right)$, and even after autoclaving. Subsequently, produced lipopeptides are proved suitable for bioremediation of crude oil (86\%) and as potent plant growth-promoting agent that significantly $(P<0.05)$ increase seed germination and plant growth promotion of chili pepper, lettuce, tomato, and pea maximum at a concentration of $(0.7 \mathrm{~g} / 100 \mathrm{~mL})$, showed as a potential agent for agriculture and bioremediation processes by lowering economic and environmental stress.
\end{abstract}

Keywords: Ecotoxicity, Bacillus subtilis SNW3, Lipopeptide, Bioremediation, Plant growth promotion

\footnotetext{
*Correspondence: safiamrl@yahoo.com

${ }^{1}$ Department of Microbiology, Faculty of Biological Sciences, Quaid-i-

Azam University, Islamabad 45320, Pakistan

Full list of author information is available at the end of the article
} 


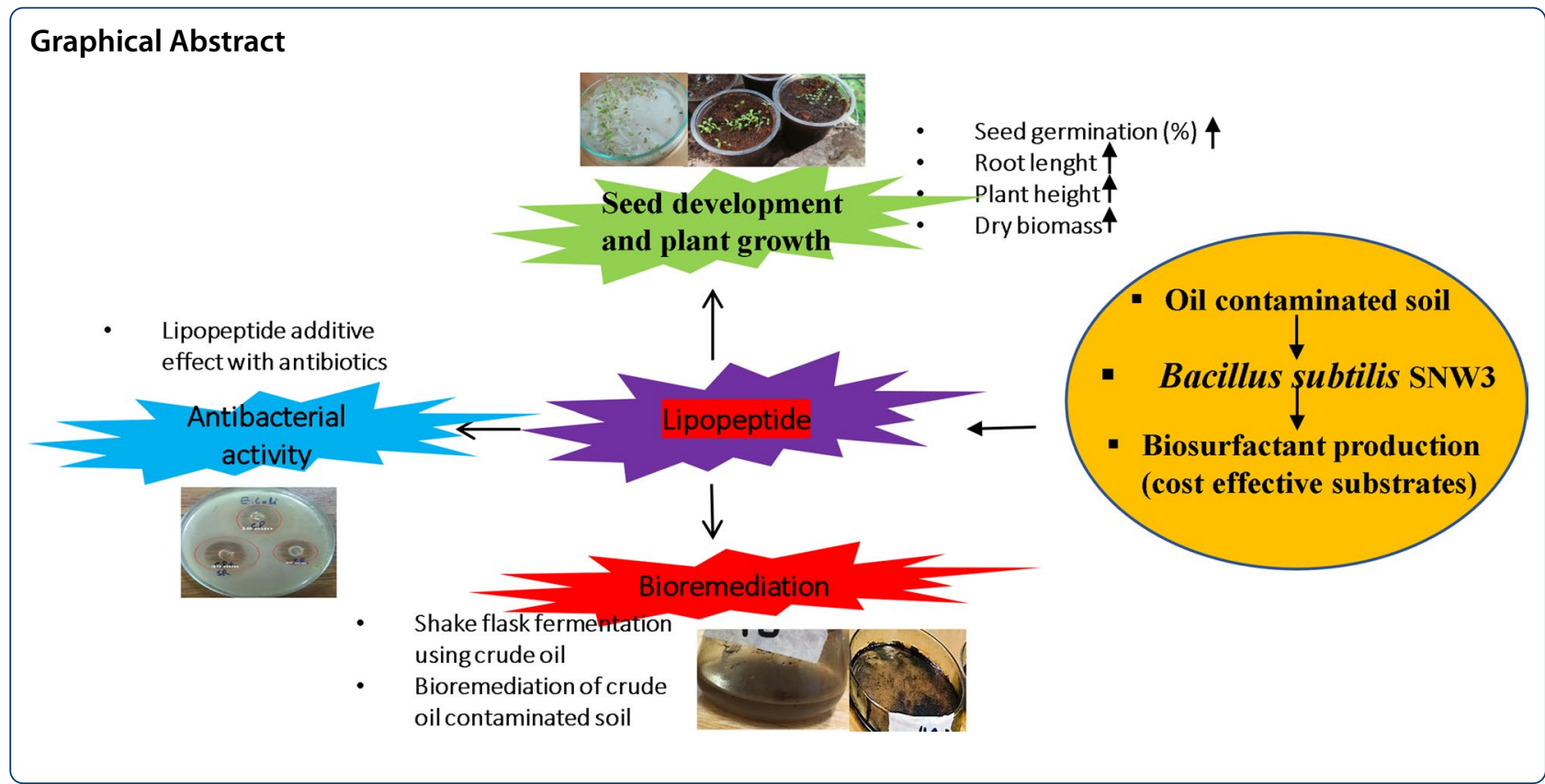

\section{Introduction}

Environmental pollution due to petroleum products such as crude oil, diesel, and gasoline is of major ecological concern nowadays (Jimoh and Lin 2019). Major health problems in humans and animals are occurred due to the release of petroleum and its by-products in a terrestrial and aquatic ecosystem because of having mutagenic, carcinogenic, and teratogenic effects (Yadav et al. 2016). Petroleum-derived pollutants result in the limitation of phosphorus, iron, and nitrogen availability in agricultural soil (Nogueira et al. 2011). In today's challenging world enhanced agricultural productivity is the need of the hour to encounter human food demands. However, equally alarming is the damage of agricultural land by pollutants that needs bioremediation strategies. Hence, researchers must focus on remediation of all these issues. Biosurfactants are amphiphilic secondary metabolites that exhibit surface-active properties produced by bacteria, fungi, and yeast (Santos et al. 2016). Biosurfactantproducing microorganisms enhance plant growth through improvement in plant immunity against organic contaminants in the environment. Furthermore, they are also efficient in alleviating stress responses in plants along with strengthening plant growth and development (Almansoory et al. 2019). The surfactin preferably and to the lower extent fengycin, lipopeptides are capable to provoke defense responses that generate signaling molecules for activation of induced systemic resistance (ISR) in plants (Ongena et al. 2007). Other lipopeptides that are reported for induction of plant defense response includes iturin (Yamamoto et al. 2015), mycosubtilin
(Farace et al. 2015), bacillomycin D (Wu et al. 2018), and sessilin and orfamide (D'aes et al. 2014). One of the positive influences of the use of lipopeptides in agriculture is its biocompatibility with living organisms (Lawniczak et al. 2013). Hence, to minimize the initial dose of fertilizers by seed stimulation strategies and its equal distribution in the soil is made possible through biosurfactants (Krawczyńska et al. 2012). Many researchers verified that plant growth-promoting rhizobacteria (PGPR) positively enhance plant development after association with the hydrocarbon-degrading bacteria in the contaminated soil (Pawlik et al. 2017). Different plant growth-promoting traits include phosphate solubilization, siderophore production, hydrogen cyanide ( $\mathrm{HCN})$ production, indole acetic acid (IAA) production, and systemic resistance induction (Benaissa 2019). Hence, for employing biosurfactants in agriculture, bioremediation and its application in other fields the reduction in cost needed for production are of absolute concern (Jimoh and Lin 2019). Increase in awareness among public about the use of environment-friendly and sustainable green products demand new strategies development to cut down the production cost for replacement of toxic synthetic surfactants with biosurfactants (Shaban and Abd-Elaal 2017). Biosurfactants with numerous useful applications provide growing interest in diverse industrial sectors including food, medicine, cosmetics, and agriculture (Patil et al. 2014). However, the production cost is still high that depends on the availability of raw materials and downstream processing for scaleup at the industrial level (Akbari et al. 2018). Raw materials used for biosurfactant 
production accounts for about $50 \%$ of the final production cost (Rufino et al. 2007). Better choice of raw material is a way to cut down the budget and make the process economically feasible (Jimoh and Lin 2019; Mukherjee et al. 2006). Unlike synthetic surfactants that are produced from petroleum feed stock, biosurfactants could be produced using waste materials like agriculture waste (wheat bran), brewery waste, and food waste by-products (potato peels and waste frying oil) that not only reduce cost but also helps in waste disposal in environmentfriendly manner (Moshtagh et al. 2018; Vea et al. 2018). In the present study, we used potato peels powder, waste frying oil, molasses, and white beans powder as a lowcost substrate for biosurfactant production. Hence, with all the above intentions the current study was conducted to produce stable potent biosurfactants employing various cost-effective renewable resources and to evaluate the potential of produced lipopeptides for detoxification and management of crude oil contaminated soil and to promote plant growth and development.

\section{Materials and methods}

\section{Materials and chemicals}

All chemicals used in the study werepurchased from Sigma-Aldrich (Merck KGaA, Darmstadt, Germany), and are of analytical grade. The standard surfactin ( $\geq 98 \%$ purity) used as a reference for lipopeptides characterization in this study was obtained from Sigma-Aldrich. Fertilizers (NPK; 20-10-10) used in the study were bought from Agro-chemicals, Fertilizers (TAK Agro Brand). Antibiotics used in the current study were purchased from Werrick Pharmaceuticals Pakistan. Crude oil used was collected from Pakistan petroleum limited.

\section{Microorganism and culture conditions}

In the current study, Bacillus subtilis SNW3 (Genbank Acc. No. JX534509.1), obtained from Microbiology Research Lab, Quaid-i-Azam University, Islamabad, was previously identified and isolated from contaminated soil of Fimkessar oil field, Chakwal, Pakistan (Malik and Ahmed 2012). This strain SNW3 also referred to as QVS1 is deposited with the Belgian Coordinated Collections of Microorganisms BCCM/LMG, Ghent, Belgium, under Accession Number "LMG P-30406". The bacterial sample was cultured on nutrient agar plates (Yeast extract 2.0; Beef extract 1.0; Peptone 5.0; Sodium chloride 5.0; Agar $15 \mathrm{~g} / \mathrm{L}$ ) incubated for $24 \mathrm{~h}$ at $30^{\circ} \mathrm{C}$ to obtain separate pure colonies, stored for regular use at $4{ }^{\circ} \mathrm{C}$ and sub-cultured before use. The strain was preserved at $-80^{\circ} \mathrm{C}$ in nutrient broth (Peptone, 5; Meat extract, 1; Yeast extract, 2.0 and sodium chloride $\mathrm{g} / \mathrm{L}$ ) supplemented with $30 \%$ glycerol.

\section{Cost-effective substrates for biosurfactant production}

For low cost biosurfactant production various cost-effective substrates were evaluated that includes: potato peels powder (total carbohydrate $68.7 \%$; starch $25 \%$; protein $18 \%$; non-starch polysaccharide $30 \%$; acid-soluble and acid-insoluble lignin 20\% and nitrogen 1.3\%) (Liang et al. 2014), molasses (total sugars 62.3\%, sucrose $48.8 \%$, starch $0.33 \%$ and ash $13.1 \%$ ) (Palmonari et al. 2020), white beans powder (protein 15.62\%; carbohydrates $60.47 \%$; lipids 2.13\%; crude fibre 14.15\%) (Alayande et al. 2012), waste frying oil (palmitic acid 15.86\%; oleic acid 29.83\%; stearic acid $4.87 \%$ and linoleic acid 28.85\%) (Banani et al. 2015) and nitrogen sources: sodium nitrite, urea and ammonium nitrate while, conventional media yeast extract (protein 62.5\%; sugar $2.90 \%$; fat $0.10 \%$; ash $9.50 \%$ ) was used as control. Each carbon source listed above was designed to use individually, then selected substrates were used in different combinations to achieve an optimized medium composition. Molasses used in current study was obtained from Chashma Sugar Mills Limited in Dera Ismail Khan (Pakistan). Potato peels and waste frying oil were obtained from café located at Quaid-i-Azam University Islamabad (Pakistan). Whereas white beans were obtained from National Agricultural Research Council (NARC) Islamabad Pakistan.

Cost-effective substrates were categorized through various methods: soluble total organic nitrogen analysis through the Kjeldahl method (Toledo et al. 2018), soluble total organic carbon with a TOC analyzer (Multi N/C 3100, Analytic Jena), and Dumas method for total organic carbon (TOC) and total organic nitrogen in the solid fraction by applying (LECO, TruSpec CHN) tool (Munera-Echeverri et al. 2020).

\section{Inoculum}

Bacillus subtilis SNW3, streaked and stored on nutrient agar plates at $4^{\circ} \mathrm{C}$ was used for inoculum preparation. A loop full of culture from a single isolated colony on plate added in $100 \mathrm{~mL}$ nutrient broth (Peptone, 5; Meat extract, 1; Yeast extract, 2.0 and sodium chloride, $5 \mathrm{~g} / \mathrm{L}$ ) incubated at $30^{\circ} \mathrm{C}$ for $48 \mathrm{~h}$ then seed culture from the nutrient broth was used as inoculum for all experiments.

\section{Production optimization, extraction, and partial purification of biosurfactant}

The strain Bacillus subtilis SNW3 was grown on conventional yeast extract media $(2 \% \mathrm{w} / \mathrm{v})$ and mineral salt medium (MSM) as described by (Abouseoud et al. 2008; Rastogi et al. 2021) of given composition (g/L: $\mathrm{KH}_{2} \mathrm{PO}_{4}$, 2.0; $\mathrm{K}_{2} \mathrm{HPO}_{4}, 4.0 ; \mathrm{FeSO}_{4} \cdot 7 \mathrm{H}_{2} \mathrm{O}, 0.025 ; \mathrm{MgSO}_{4} \cdot 7 \mathrm{H}_{2} \mathrm{O}$, 1.0; KCl, 0.2; $\mathrm{NaCl}, 5.0 ; \mathrm{CaCl}_{2} \cdot 2 \mathrm{H}_{2} \mathrm{O}, 0.02$; and trace elements solution with composition of $\mathrm{MnSO}_{4} \cdot 4 \mathrm{H}_{2} \mathrm{O}, 1.78$; 
Table 1 Optimization of low-cost substrate and culture conditions for lipopeptide production by Bacillus subtilis SNW3

\begin{tabular}{|c|c|}
\hline Factors & Ranges \\
\hline Temperature $\left({ }^{\circ} \mathrm{C}\right)$ & $15,30,37$ and 50 \\
\hline $\mathrm{pH}$ & $2,4,6,8,10,12$ \\
\hline Agitation speed (rpm) & $0,150,250$ \\
\hline Inoculum size $(\%, w / v)$ & $0.5,1,1.5,2,2.5$ \\
\hline Nitrogen source $(0.1 \%, w / v)$ & Urea, sodium nitrate, ammonium nitrate \\
\hline Carbon source (conc. 2\%, w/v) & $\begin{array}{l}\text { White beans powder, potato peels powder, } \\
\text { molasses, waste frying oil, yeast extract }\end{array}$ \\
\hline Carbon and nitrogen source ratio (W.B.P + W.F.O + U) w/v & $11+0.5+0.1,8+1+0.1,6+1.5+0.1,3+2+0.1$ \\
\hline
\end{tabular}

$\mathrm{ZnSO}_{4} \cdot 7 \mathrm{H}_{2} \mathrm{O}, 2.32 ; \mathrm{CuSO}_{4} \cdot 5 \mathrm{H}_{2} \mathrm{O}, 1.0 ; \mathrm{H}_{3} \mathrm{BO}_{3}, 0.56 ; \mathrm{KI}$, 0.66 and $\left.\mathrm{NH}_{4} \mathrm{MoO}_{4} \cdot 2 \mathrm{H}_{2} \mathrm{O}, 0.39\right)$. Different environmental process parameters significant for biosurfactant production were evaluated using above mentioned media at various range of temperature $\left(15,30,37\right.$ and $\left.50^{\circ} \mathrm{C}\right), \mathrm{pH}$ $(2,4,6,8,10,12)$, agitation speed $(0,150$ and $250 \mathrm{rpm})$ and inoculum size $(0.5,1,1.5,2$ and 2.5$)$. Initially, three nitrogen sources (urea, sodium nitrate, and ammonium nitrate) and four cost-effective substrates (white beans powder, potato peels powder, waste frying oil, and molasses) were tested separately. After that for different combinations, the selected nitrogen source and cost-effective substrates added with MSM were used in various combined media compositions. Optimization of substrate and culture conditions are given in (Table 1). Yeast extract as the most preferable substrate for biosurfactant production was used as control media (Qazi et al. 2013). The designed experiments for substrate evaluation were run with $100 \mathrm{~mL}$ media in $250 \mathrm{~mL}$ Erlenmeyer flask with $\mathrm{pH}$ adjusted to $7.0 \pm 0.2$ and kept in a shaker for $96 \mathrm{~h}$ of incubation at $30^{\circ} \mathrm{C}$ and $150 \mathrm{rpm}$. The cell-free supernatant obtained after centrifugation at 12,000 rpm was acidified up to $\mathrm{pH} 2.0$ with $1 \mathrm{M}$ hydrochloric acid (HCL) and kept overnight at $4{ }^{\circ} \mathrm{C}$. For bacterial biomass production, the collected pallet was washed with saline solution $(0.9 \% \mathrm{w} / \mathrm{v} \mathrm{NaCl})$, oven-dried at $100^{\circ} \mathrm{C}$, and weighted (Guerfali et al. 2020).

\section{Dry weight of lipopeptides}

For crude biosurfactants, pelleted precipitates were extracted with chloroform/methanol (2:1) and concentrated by rotary evaporation (Marchut-Mikolajczyk et al. 2018). After that concentrate was poured into a preweighted sterile beaker. The crude lipopeptides were ovendried at $60{ }^{\circ} \mathrm{C}$ for $24 \mathrm{~h}$. Plates were weighted after drying (Anandaraj and Thivakaran 2010). The following formula was used to calculate the dry weight of crude lipopeptide extract produced by Bacillus subtilis SNW3 under optimized substrate and culture conditions. Dry weight of lipopeptide produced $=($ Weight of plate containing dried lipopeptide - Empty plate weight).

\section{Assessment of biosurfactant production}

For quantitative analysis of biosurfactant production, various assays were used that include surface tension measurement (SFT), oil displacement assay (ODA), and emulsification index (E24). The sample used for analysis was in the form of cell-free supernatant (CFS).

\section{Oil displacement activity (ODA)}

For estimation of biosurfactant production oil displacement activity (ODA) was performed according to the method of Yalçın et al. (2018). Briefly, $20 \mu \mathrm{L}$ of crude oil was add on the surface of $40 \mathrm{~mL}$ distilled water in the petri dish. The cell-free supernatant (CFS) of $10 \mu \mathrm{L}$ was placed gently on a uniform crude oil layer formed on distilled water. Oil layer was displaced, and clear zone diameter was measured in centimetre $(\mathrm{cm})$. Production medium without inoculum was used as negative control. Clear zone formation indicates biosurfactant presence in CFS.

\section{Emulsification index (E24)}

Emulsification index (E24\%) was used to estimate the emulsifying capacity of the biosurfactant, performed through protocol of Ferhat et al. (2011) with minor modifications. In short, kerosene oil ( $2 \mathrm{~mL})$ and an equal volume of cellfree supernatants were added in the test tube and mixed for $2 \mathrm{~min}$ on the vertex mixer. After that, these test tubes were kept undisturbed for $24 \mathrm{~h}$ at room temperature. The percent emulsification was measured using given formula where heights were calculated in centimetres $(\mathrm{cm})$.

$$
\mathrm{E}_{24}(\%)=\frac{\text { Height of the emulsion }(\mathrm{cm})}{\text { Total height of the solution }(\mathrm{cm})} \times 100 .
$$

\section{Surface tension (SFT) measurement}

For quantitative analysis of biosurfactant produced by Bacillus subtilis SNW3 surface tension (SFT) of the cell-free supernatant was measured in $\mathrm{mN} / \mathrm{m}$ by using 
KRUSS K20 digital Tensiometer (Kruss GmbH, Hamburg, Germany). SFT measurement was performed at room temperature by Wilhelmy plate through according to the protocol given by the manufacturer. Cell-free supernatant of 25 to $30 \mathrm{~mL}$ was put on the tensiometer platform in a glass cup. Wilhelmy plate was sterilized before use, adjusted on the tensiometer, submerged in the broth followed by surface tension measurement (Novikov et al. 2017).

\section{Structural characterization of lipopeptide by thin-layer chromatography (TLC) and Fourier transform infrared spectroscopy (FTIR)}

For thin-layer chromatography (TLC) and Fourier transform infrared spectroscopy (FTIR) analysis, extracted form of crude biosurfactant was used while surfactin a class of lipopeptide (from sigma) was taken as standard for initial characterization. Crude biosurfactant components were separated on Silica coated aluminum plates, silica gel 60 F254, MERCK Germany using chloroform: methanol: acetic acid (85:10:5, v/v) visualized under the wavelength of 254 and $365 \mathrm{~nm}$ to find retention factor (Rf) (Joy et al. 2017). For determination of chemical nature of bonds and, functional groups present in the crude form of biosurfactant produced FTIR analysis was performed. $10 \mathrm{mg}$ of crude biosurfactant was loaded and the spectrum was observed at the range of 4500$450 \mathrm{~cm}^{-1}$ using Tensor 27 (Bruker) FTIR spectrophotometer, equipped with ZnSe ATR (Marchut-Mikołajczyk et al. 2019).

\section{Determination of critical micelles concentration (CMC) and critical micelle dilution (CMD) of lipopeptides}

The CMC of the produced biosurfactant was analyzed through change in surface tension reduction values with varying concentrations of 0.06 to $1.24 \mathrm{mg} / \mathrm{mL}$ prepared in demineralized water (Datta et al. 2018). For critical micelle dilution cell, free supernatant was diluted10-folds up to three levels (i.e. $10 \times, 100 \times$, and $1000 \times$ ) named as $\mathrm{CMD}^{-1}, \mathrm{CMD}^{-2}$, and $\mathrm{CMD}^{-3}$, respectively. Surface tension reduction value was analyzed by Wilhelmy plate method using KRUSS K20 digital Tensiometer (Kruss $\mathrm{GmbH}$, Hamburg, Germany), performed at room temperature (Campos et al. 2019).

\section{Lipopeptides stability studies}

To elucidate the thermal stability of lipopeptide, thestandard solutions of crude biosurfactant were prepared at a concentration of $600 \mathrm{mg} / \mathrm{L}$ and incubated at different temperatures $\left(20-121^{\circ} \mathrm{C}\right)$ for $1 \mathrm{~h}$. Furthermore, a stability test of the produced lipopeptide at saline conditions was performed. Different concentrations of sodium chloride $\mathrm{NaCl}(1-10 \%)$ were added to the biosurfactant solutions and incubated at $30{ }^{\circ} \mathrm{C}$ for $1 \mathrm{~h}$. To determine $\mathrm{pH}$ effect on lipopeptide activity different buffer solutions were prepared and added to the biosurfactant standard solution, adjusted to $\mathrm{pH} 1-5$ using citrate-phosphate buffer, pH 7 using phosphate buffer, and pH 9-11 using carbonate-bicarbonate buffer solutions, incubated for $30 \mathrm{~min}$. The stability of the produced lipopeptide was checked through surface tension reduction value of each treated sample (Goswami and Deka 2019).

\section{Functional characterization of the lipopeptides Lipopeptide screening for antimicrobial activity}

Lipopeptide for its antimicrobial potential was assessed through well diffusion assay as mentioned before Singh et al. (2014). Mueller-Hinton agar plates were prepared to contain Escherichia coli ATCC 25922 and Salmonella typhi ATCC 14028. The crude lipopeptide $(10 \mathrm{mg} / \mathrm{mL})$, ciprofloxacin and clarithromycin $(1 \mathrm{mg} / \mathrm{mL})$, and biosurfactant in addition with antibiotics $(5: 0.5 \mathrm{mg} / \mathrm{mL})$ were poured at a concentration of $100 \mu \mathrm{L}$ and kept at $37^{\circ} \mathrm{C}$ for $24 \mathrm{~h}$ of incubation. To determine the bacterial sensitivity to lipopeptide, the diameter of inhibition zone $(\mathrm{mm})$ was measured according to Clinical Laboratory Standards Institute (Wayne 2002). To investigate the additive effect of lipopeptide with antibiotics any increase in the diameter of the inhibition zone was measured as compared to antibiotics. Antibiotics without biosurfactants were used as a positive control (Ekprasert et al. 2020).

\section{Exploration of lipopeptides for seeds germination and plant growth}

The seeds of tomato (Solanum Lycopersicum), pea (Pisum sativum), chili pepper (Capsicum annuum), and lettuce (Lactuca sativa) were collected from National Agricultural Research Centre (NARC) Islamabad, Pakistan. Obtained seeds were surface sterilized with $10 \% \mathrm{Na}-$ hypochlorite for $20 \mathrm{~min}$ and then washed with sterile distilled water before use. The crude lipopeptide extract produced with cost-effective optimized media was used in this assay. The seed germination experiment was conducted in a petri plate containing 40 seeds positioned in filter paper and cotton soaked with four different concentrations $(0.1,0.3,0.5$, and $0.7 \mathrm{~g} / 100 \mathrm{~mL})$ of crude lipopeptide solution. Distilled water $100 \% \mathrm{v} / \mathrm{v}$ was used as a control. These plates were kept in yellow light at $25^{\circ} \mathrm{C}$ for 7 days after that relative seed germination (G, \%): [No. of seeds germinated (treatment)/No. of seeds germinated $($ control $) \times 100$ ] was calculated. Following the germination test seeds treated with lipopeptide solution were transferred in pots (seeds without pre-treatment with biosurfactant were used as control) and kept in a greenhouse with temperature maintained between 20 and $22{ }^{\circ} \mathrm{C}$. Furthermore, for plant growth stimulation crude 
Table 2 Different design treatments for removal of crude oil from contaminated soil

\begin{tabular}{|c|c|c|c|c|}
\hline Treatments & Soil & Biological treatment & Chemical compounds & $\begin{array}{l}\text { Crude oil } \\
\text { concentration } \\
(\%)\end{array}$ \\
\hline Control (T0) & $200 \mathrm{~g}$ & & & 5 \\
\hline Treatment 1 (T1) & $200 \mathrm{~g}$ & $\begin{array}{l}\text { Cell-free supernatant containing } \\
\text { lipopeptide }(200 \mathrm{~mL})\end{array}$ & & 5 \\
\hline Treatment 2 (T2) & $200 \mathrm{~g}$ & $\begin{array}{l}\text { Active culture of Bacillus subtilis } \\
\text { SNW3 ( } 100 \mathrm{~mL})\end{array}$ & & 5 \\
\hline Treatment 3 (T3) & $200 \mathrm{~g}$ & $\mathrm{~T} 1(100 \mathrm{~mL})+\mathrm{T} 2(100 \mathrm{~mL})$ & & 5 \\
\hline Treatment 4 (T4) & $200 \mathrm{~g}$ & & $10 \mathrm{mg} / \mathrm{kg}$ of tween 80 & 5 \\
\hline Treatment 5 (T5) & $200 \mathrm{~g}$ & & $0.8 \mathrm{~g} / \mathrm{kg}$ of fertilizer & 5 \\
\hline Treatment 6 (T6) & $200 \mathrm{~g}$ (autoclaved) & & & 5 \\
\hline
\end{tabular}

lipopeptide solution was added in pots at a concentration $(0.1,0.3,0.5$, and $0.7 \mathrm{~g} / 100 \mathrm{~mL})$ dissolved in distilled water thrice with 10 days interval while in control pots pure water was added. The emergence of plant seedlings was tested and checked for the morphological characteristic of plants like shoot length $(\mathrm{mm})$, root length $(\mathrm{mm})$, and dry weight (g) of plants after 40 days (Huang et al. 2017).

\section{Bioremediation assay in shake flask fermentation}

The biodegradation efficiency of crude oil by Bacillus subtilis SNW3 was analyzed as illustrated by Varjani and Upasani (2016) with minor changes. An aliquot of $2 \mathrm{~mL}$ pre cultured Bacillus subtilis SNW3 was transferred into $250 \mathrm{~mL}$ of Erlenmeyer flask containing $100 \mathrm{~mL}$ mineral salt media and different concentrations $0.5,1,1.5$, and $2 \%(\mathrm{v} / \mathrm{v})$ of crude oil. For monitoring of abiotic loss of the crude oil, an uninoculated media was used as control. All these flasks were incubated for 21 days at $200 \mathrm{rpm}$ and $35 \mathrm{C}$. The bacterial growth in crude oil was detected through measurement of the absorbance at (OD600 nm) through spectrophotometer while SFT was measured by tensiometer. To estimate the residual crude oil in media, crude oil was extracted with hexane, left for evaporation in a pre-weight clean beaker. For quantification of remaining crude oil after degradation gravimetric analysis was performed at different time intervals by following the formula proposed by Patowary et al. (2017). for removing hydrophobic pollutants from soil was analyzed by collecting 5-10 cm deep topsoil while following the protocol of Okop et al. (2012) and transported in a clean container to the Microbiology laboratory of Quaidi-Azam University Islamabad Pakistan. The soil collected was air dried and sieved with a $2 \mathrm{~mm}$ sieve after that $5 \%$ of crude oil was sprayed on the soil to pollute soil homogenically. The polluted soil was left undisturbed for 5 days and then divided into $200 \mathrm{~g}$ of equal parts and dispensed in pots. These pots were left undisturbed in the open air for a week. Then for conducting bioremediation experiments various designed treatments were established added twice throughout the remediation period: (T0) addition of distilled water as control, (T1) cell-free supernatant obtained after $96 \mathrm{~h}$ of incubation with maximum biosurfactant produced by using optimized costeffective substrate media, (T2) addition of active culture of Bacillus subtilis SNW3 (2\% inoculum size) cultured in nutrient broth kept in shaker incubator at $30{ }^{\circ} \mathrm{C}, 150 \mathrm{rpm}$ for $24 \mathrm{~h}$ of incubation, (T3) effect of two additives was assessed for bioremediation i.e. T1 + T2, (T4) addition of tween 80 (T5) addition of fertilizer (NPK; 20-10-10) to analyse the effect of fertilizer on bioremediation in comparison to the produced lipopeptide (Pelletier et al. 2004) and (T6) an additional control containing autoclaved soil and $5 \%$ crude oil $(\mathrm{w} / \mathrm{v})$ was used to examine the crude oil degradation in the soil. Detailed information about all the above treatments is shown in (Table 2). The soil

Hydrocarbon degradation \% = Amount of crude oil degraded/Amount of crude oil 100.

\section{Bioremediation of crude oil in the soil through various design treatments}

In this assay bioremediation of crude oil contaminated soil was monitored by collecting garden soil from Quaidi-Azam University Islamabad. Biosurfactant suitability content of each pot was tilled twice a week for aeration with moisture maintenance at $60 \%$ and temperature of $28-30^{\circ} \mathrm{C}$, providing all those conditions that are appropriate for crude oil-degrading microbes present in the soil (Agamuthu et al. 2013). After that soil samples of $10 \mathrm{~g}$ 

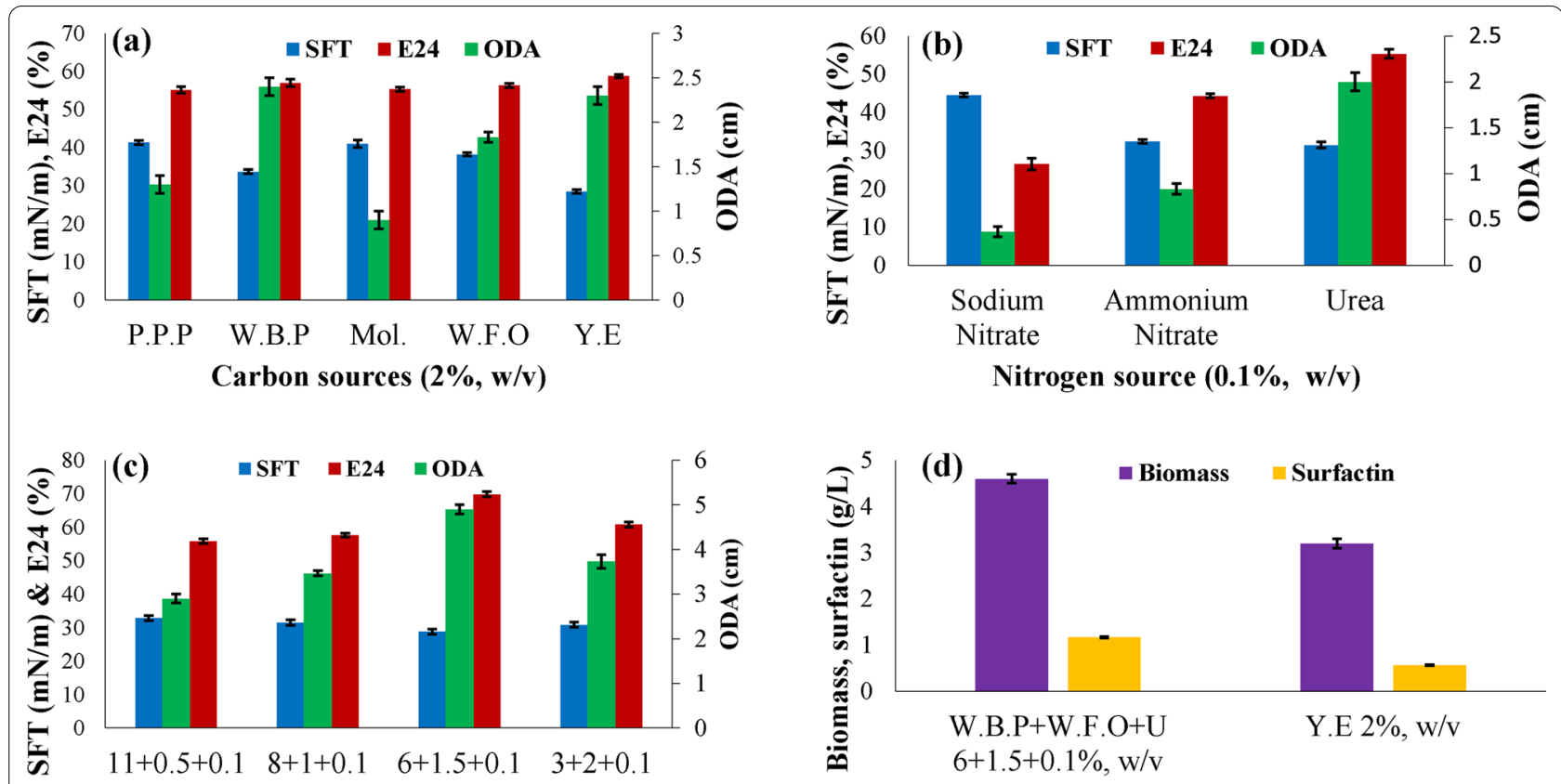

Carbon and nitrogen sources $(\%, w / v)$

Media composition

Fig. 1 SFT, E24 and ODA values for lipopeptide production by Bacillus subtilis SNW3 a with alternative carbon sources used individually, b different nitrogen sources, $\mathbf{c}$ with a combination of carbon and nitrogen energy sources and $\mathbf{d}$ production analysis of surfactin under optimized conditions with yeast extract as a reference, in shake flask fermentation at $30^{\circ}$ C. P.P.P: potato peels powder; W.B.P: white beans powder; Mol.: molasses; W.F.O: waste frying oil; Y.E: yeast extract

were collected from different areas of the plastic pots at the 30,60 , 90th day and were gravimetrically determined using the formula given by Ganesh and Lin (2009).

\section{Statistical analysis}

The obtained results were analyzed statistically with the use of STATISTICA software, one-way ANOVA (version 8.1). The difference between obtained results was analyzed by using Tukey's test to find individual and control mean \pm standard deviation. Significance value was set at $\mathrm{p}=0.05$ and $\mathrm{p}$-values $\leq 0.05$ were considered significant.

\section{Results}

\section{Substrate screening and optimization studies} for lipopeptide production

Potato peels powder, molasses, white beans powder, and waste frying oil were evaluated as cheap media for lipopeptide production by Bacillus subtilis SNW3. Optimized results for culture conditions with $2 \%$ yeast extract media showed $30{ }^{\circ} \mathrm{C}$ as optimum for maximum lipopeptide production with an ODA value of $1.26 \mathrm{~cm}$ While other optimized cultural conditions were with $1 \%$ inoculum size, $150 \mathrm{rpm}$, and $\mathrm{pH}$ of 6 (Additional file 1: Fig. $\mathrm{S} 1$ ). At the end of the fermentation process, the obtained ODA values were $1.3,2.4,0.9$, and $1.8 \mathrm{~cm}$ for potato peels powder, white beans powder, sugar cane molasses, and waste frying oil media respectively with $2 \% \mathrm{w} / \mathrm{v}$ concentration. Additionally, the surface tension reduction values observed for all four biosurfactant solutions were reduced from $72 \mathrm{mN} / \mathrm{m}$ to 41.3 (potato peels powder), 33.6 (sugar cane molasses), 41 (white beans powder) and $38.2 \mathrm{mN} / \mathrm{m}$ (waste frying oil). Though good emulsification values of all these biosurfactant solutions were obtained to about 55 to $57 \%$ (Fig. 1a). In the current study among nitrogen sources tested preferably urea act as a good nitrogen source that showed surface tension reduction of $31.4 \mathrm{mN} / \mathrm{m}$ and ODA value of $2 \mathrm{~cm}$ (Fig. 1b). It was observed that white beans powder and waste frying oil gave significant oil displacement value. the The characterization of substrate samples in terms of total organic carbon and nitrogen content of the yeast extract, white beans powder and potato peels powder used in this study is presented in Additional file 1: Table S1. It has been also found that combination of carbon sources enhances biosurfactant synthesis. The final optimized cost effective media was [white beans powder $(6 \% \mathrm{w} / \mathrm{v})+$ waste frying oil $(1.5 \% \mathrm{w} / \mathrm{v})+$ urea $(0.1 \% \mathrm{w} / \mathrm{v})]$ with significant lipopeptide yield indicated ODA of $4.9 \mathrm{~cm}$, emulsification index of $69.8 \%$ and surface tension reduction value up to 28.8 mN/m (Fig. 1c; Additional file 1: Fig. S5a, b). 


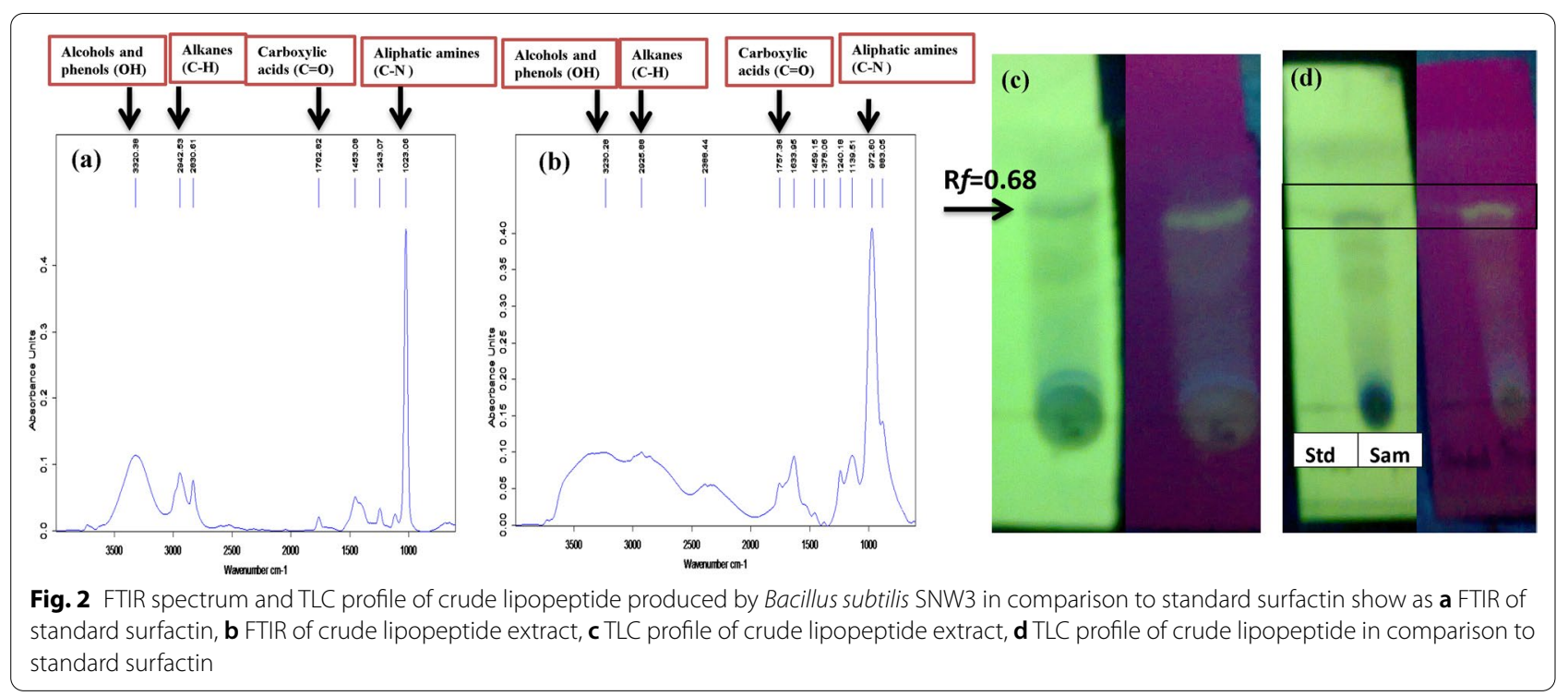

We aimed the use of alternative non-conventional media for lipopeptide production with optimized media gave $1.17 \mathrm{~g} / \mathrm{L}$ of crude lipopeptide that was almost double from $0.56 \mathrm{~g} / \mathrm{L}$ with yeast extract control media, with biomass yield of 4.6 and $3.2 \mathrm{~g} / \mathrm{L}$ respectively (Fig. $1 \mathrm{~d}$ ). The cost effective usage of media component showed that on average $1 \mathrm{~kg}$ of white beans powder with $240 \mathrm{~mL}$ of waste frying oil and $640 \mathrm{~g}$ of yeast extract media would be enough for preparing $16 \mathrm{~L}$ of fermentation media that gave $1.17 \mathrm{~g} / \mathrm{L}$ of surfactin production.

\section{Thin layer chromatography analysis}

Characterization of crude biosurfactant produced with final optimized media by Bacillus subtilis SNW3 was carried out by thin-layer chromatography (TLC) and Fourier transform infrared spectroscopy (FTIR). Results obtained by TLC indicate the lipopeptide nature of the biosurfactant product with most prominentband observed against standard surfactin having retention factor (Rf) value of 0.68 as illustrated in (Fig. 2c, d).

\section{Structural characterization of biosurfactant produced by FTIR}

The FTIR spectra represent the presence of carboxylic functional groups and aliphatic amines the characteristic of the lipopeptide nature of biosurfactant produced. The FTIR spectra show a sharp peak at $1023 \mathrm{~cm}^{-1}$ and $972 \mathrm{~cm}^{-1}$ that corresponds to the presence of $\mathrm{C}-\mathrm{N}$ aliphatic amines in standard and crude biosurfactant (Fig. 2a, b). The peaks in FTIR spectra at 1450 and 1130 suggest the presence of stretching bands between carbon atoms and hydroxyl groups. The absorbance appears at $1762 \mathrm{~cm}^{-1}$ and $1757 \mathrm{~cm}^{-1}$ attributed to the vibrations due to the ester carbonyl group of peptide components. The peaks observed in FTIR spectra at 2942 and 2926 corresponds to the presence of $\mathrm{C}-\mathrm{H}$ bands $\left(\mathrm{CH}_{2}-\mathrm{CH}_{3}\right.$ stretching). Another peak ranging from 3500 to $3200 \mathrm{~cm}^{-1}$ indicated the presence of alcohols and phenols $(\mathrm{O}-\mathrm{H}$ stretch, $\mathrm{H}$-bond). The spectra presented in the current study in comparison to standard surfactin from sigma suggested the presence of peptide moiety and aliphatic groups, a distinctive feature of lipopeptides nature of biosurfactant produced by Bacillus subtilis SNW3.

\section{Lipopeptide screening for antimicrobial activity}

In this study, we observed that lipopeptides produced by Bacillus subtilis SNW3 showed antimicrobial and synergistic effects with antibiotics against Escherichia coli and Salmonella typhi. In the case of lipopeptide alone, the growth of $E$. coli was affected more as compared to S. typhi. However, in combination with antibiotics, the results obtained showed an increase in zone of inhibition from 18 to $30 \mathrm{~mm}$ for E. coli and 42 to $45 \mathrm{~mm}$ for $S$. typhi containing lipopeptide plus ciprofloxacin (Fig. 3a). Thus, the addition of lipopeptide renders bacteria more sensitive to ciprofloxacin used in the case of $E$. coli. Similarly, the inhibition zone around lipopeptide plus clarithromycin increased from 20 to $30 \mathrm{~mm}$ and 19 to $25 \mathrm{~mm}$ for E. coli and S. typhi (Fig. 3b). In general, lipopeptide showed antibacterial and an additive effect while used in combination with antibiotics, shown in Additional file 1: Fig. S2. 

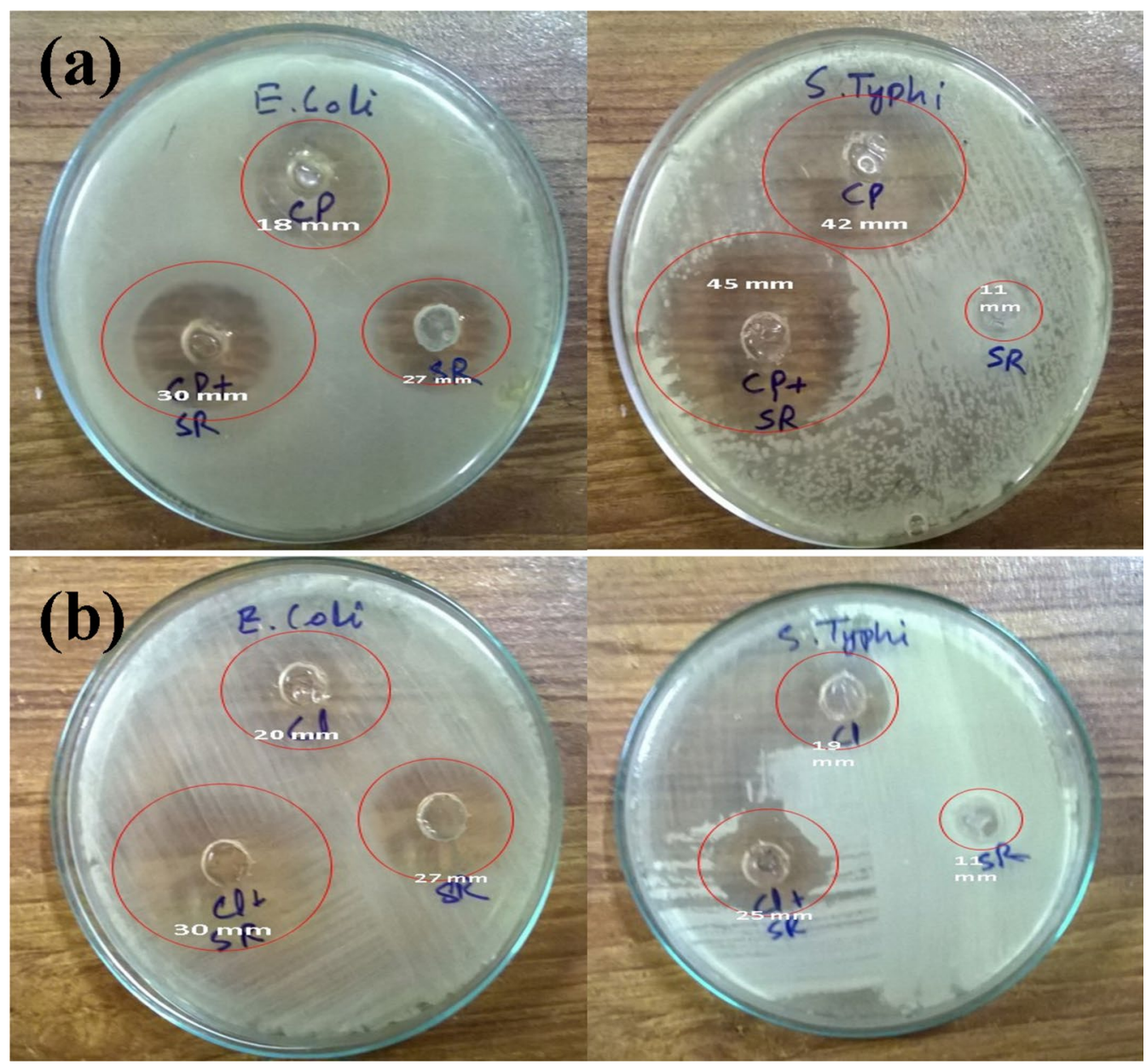

Fig. 3 Antibiogram of crude lipopeptide extract tested with antibiotics a ciprofloxacin and $\mathbf{b}$ clarithromycin, against Escherichia coli and Salmonella typhi

\section{Critical micelle concentration (CMC) and critical micelle dilution (CMD) determination}

The crude biosurfactant obtained from Bacillus subtilis SNW3 which was dissolved in distilled water at different concentrations showed a reduction in surface tension of water from 72 to $36 \mathrm{mN} / \mathrm{m}$ with an increase in lipopeptide concentration. Lipopeptide produced seems to be more competent exhibited a CMC at $0.5 \mathrm{mg} / \mathrm{mL}$, with surface tension reduction of $36 \mathrm{mN} / \mathrm{m}$ (Additional file 1: Fig. S3a). The surface tension values remain stable with an SFT value of $29 \mathrm{mN} / \mathrm{m}$ to $32 \mathrm{mN} / \mathrm{m}$ after making threefold dilutions showing effective lipopeptide concentration in the medium (Additional file 1: Fig. S3b).

\section{Stability studies}

The applicability of biosurfactant produced depends on its behavior shows at different conditions of temperature, pH, and salinity (Gudina et al. 2010). The lipopeptide produced during the current study was found to be more stable after exposure to various temperatures ranges since no significant difference was detected for surface tension reduction values from 20 to $121{ }^{\circ} \mathrm{C}$. The favorable surface tension reduction values were observed over a $\mathrm{pH}$ range of 1 to 11, although in between $\mathrm{pH} 5$ to 7 lipopeptides produced was found to be more stable (Fig. 4). At $\mathrm{pH} 1$, surface tension value raised slightly up to $35 \mathrm{mN} / \mathrm{m}$ that means that produced lipopeptides possess stability at acidic conditions but more effectively stable at alkaline conditions. Besides this, lipopeptide exhibit stablity over a wide range of salt concentrations 1 to $8 \%$, an increase in SFT value at $10 \% \mathrm{NaCl}$ concentration.

\section{Effect of lipopeptide on plant growth promotion}

In this study, Solanum lycopersicum (tomato), Pisum sativum (pea), Capsicum annuum (chili pepper), and Lactuca sativa (lettuce) were examined to demonstrate the effects of biosurfactants, that showed significantly $(P<0.05)$ better effects on seed germination and plant 


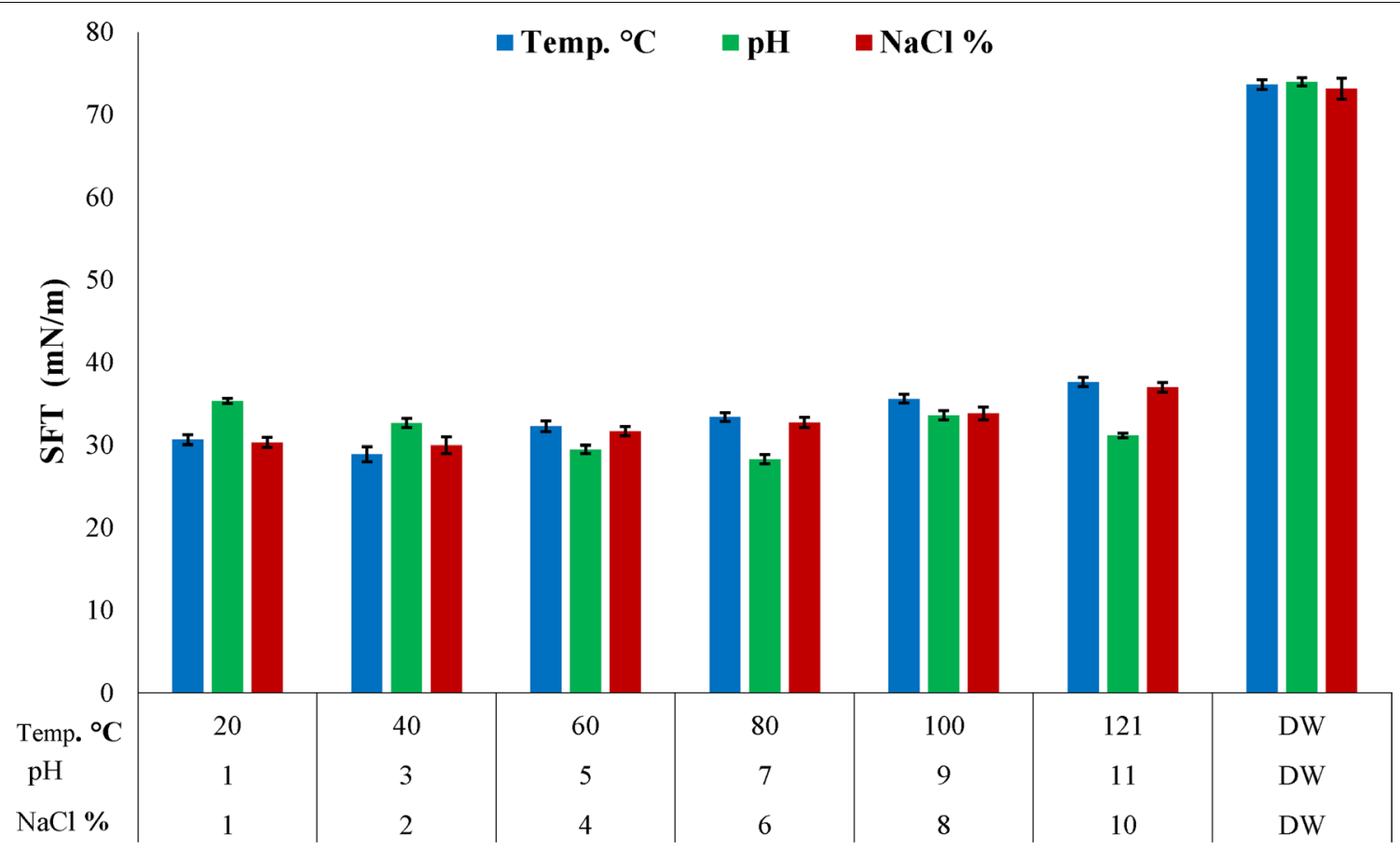

Fig. 4 Stability of crude lipopeptide extract against various environmental factors like temperature ranges $20-121{ }^{\circ} \mathrm{C}, \mathrm{NaCl}$ conc. $1-10 \%(\mathrm{w} / \mathrm{v})$ and $\mathrm{pH}$ ranges 1-11. DW distilled water, Temp temperature, $\mathrm{NaCl}$ sodium chloride

growth promotion. Statistical data about seeds germination and plants growth obtained is shown in Additional file 1: Table S2. The best results for germination were obtained at higher concentrations $(0.7 \mathrm{mg} / \mathrm{mL})$ of lipopeptide tested. Among all seeds tested significant $(\mathrm{P}<0.05)$ stimulation was observed for chili pepper seeds, showed almost double $51.7 \%$ germination at $0.5 \mathrm{~g} / 100 \mathrm{~mL}$ in comparison to control $21.6 \%$ with MilliQ water. Similarly, tomato seeds showed $68.75 \%$ germination at $0.7 \mathrm{~g} / 100 \mathrm{~mL}$ in comparison to control water $(56.25 \%)$, while pea and lettuce seeds were affected to some extent as shown in (Additional file 1: Fig. S4a).

The applied biosurfactant treatments also augmented the dry biomass of plants. The plants that arose after treating with different concentrations of lipopeptide displayed higher biomass in comparison to control. Our current findings showed that a significant $(\mathrm{P}<0.05)$ increase in weight was observed for chili pepper and lettuce at $0.7 \mathrm{~g} / 100 \mathrm{~mL}$ of lipopeptide. Biomass exhibited by chilli and lettuce was $0.21 \mathrm{~g}$ and $0.25 \mathrm{~g}$ respectively, that is four times increase in relative to control $0.06 \mathrm{~g}$ of the seedling. Although for pea and tomato similarly a positive effect was noted with the addition of $0.7 \mathrm{~g} / 100 \mathrm{~mL}$ of lipopeptide that significantly increase $(\mathrm{P}<0.05)$ dry biomass almost double in relative to control (Additional file 1: Fig. S4b). Interestingly, in the present study positive effect of lipopeptide on dry biomass was observed for all seeds tested but maximum for chili pepper and lettuce.

Almost all surfactin concentrations tested showed an immense effect on root elongation. The plants treated with a higher concentration of lipopeptide $0.7 \mathrm{~g} / 100 \mathrm{~mL}$ enhanced the root growth at maximum. Biosurfactant treatment signifies $(P<0.05)$ better elongation of seedling roots in lettuce, pea, and chili pepper almost two times greater than control. The tomato seedlings treated with lipopeptide also showed an increase in root development (Additional file 1: Fig. S4c).

All lipopeptide concentrations tested showed significant effect on plant growth parameters. The chili pepper plants showed a significant $(\mathrm{P}<0.05)$ difference in height $8.06 \mathrm{~mm}$ after treatment with $0.7 \mathrm{~g} / 100 \mathrm{~mL}$ of lipopeptides almost double as compared to control (Additional file 1: Fig. S4d). Whereas lettuce plants showed a gradual increase in height with an increase in lipopeptide concentration. The effects of lipopeptide on seed germination and plant growth promotion are shown in Fig. 5.

\section{Bioremediation assay using shake flask fermentation}

Biosurfactants are used to emulsify hydrocarbons with the reduction in surface tension, enhancement of water solubility, and increasing oil displacement from soil particles (Andrade Silva et al. 2014; Geetha et al. 2018). In the present study, the pattern for Bacillus subtilis SNW3 

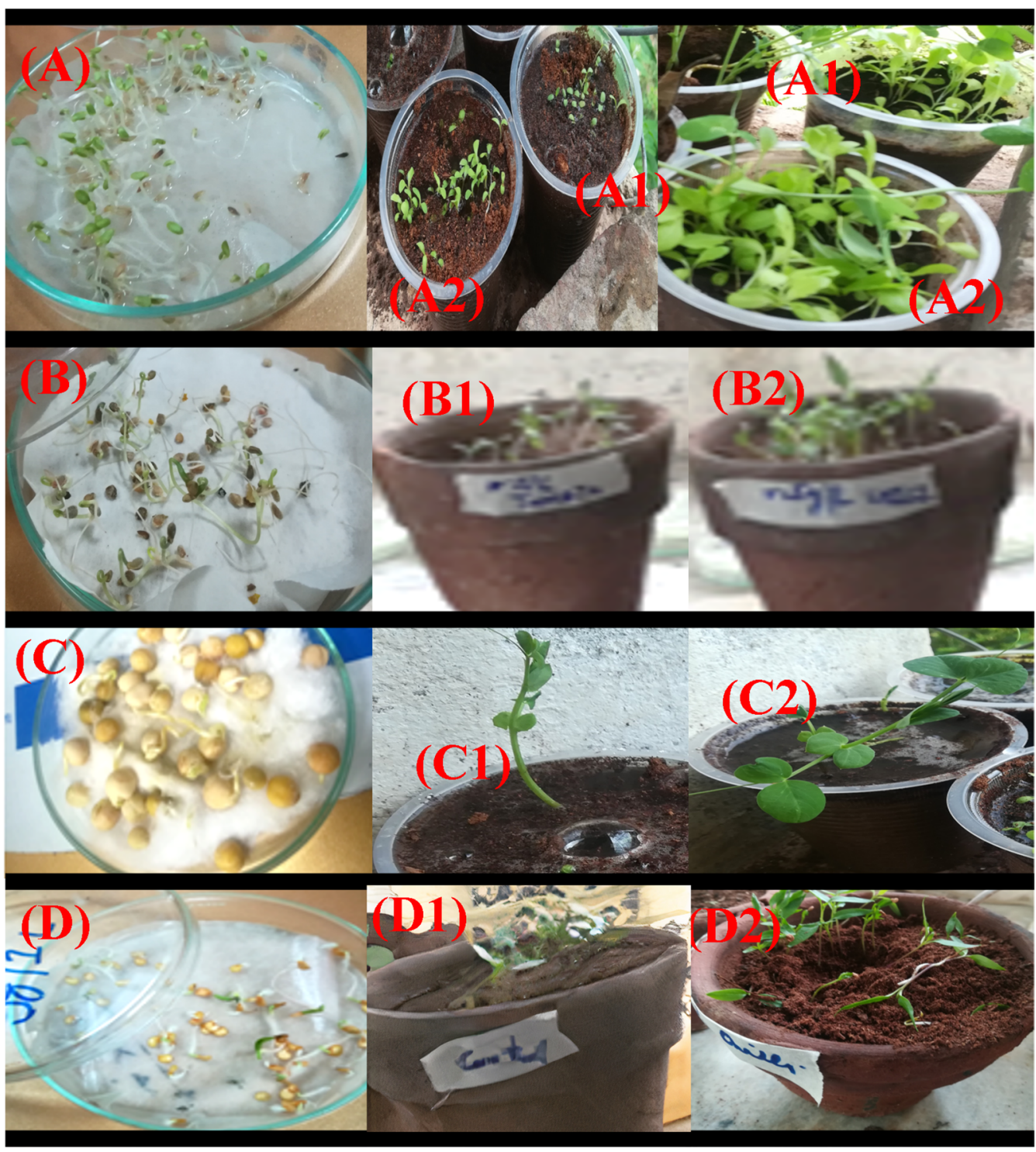

Fig. 5 Effect of crude lipopeptide extract on seed germination of $\mathbf{A}$ lettuce, $\mathbf{B}$ tomato, $\mathbf{C}$ beans, and $\mathbf{D}$ chili The portion (A-D1) show untreated control plants and (A-D2) for plants treated with lipopeptide extract at $0.7 \mathrm{~g} / \mathrm{mL}$ for 40 days

growth on crude oil and MSM revealed that there was an increase in microbial growth up to 13 days of incubation, whereas after that decline in growth was recorded. Observable effects on growth were observed with 1 and $1.5 \%$ of crude oil used. With increase in microbial growth the SFT value of the culture medium reduced from 72 to $29 \mathrm{mN} / \mathrm{m}$, indicates the lipopeptide production by Bacillus subtilis SNW3 (Fig. 6a). The simultaneous microbial growth and crude oil biodegradation in culture broth media demonstrate utilization of various components of crude oil by Bacillus subtilis SNW3 (Patowary et al. 2017). However, we observed that maximum degradation
$86 \%$ was achieved with $1.5 \%$ crude oil as compared to control (Fig. 6b; Additional file 1: Fig. S5c, d). Schematic diagram showing bacterial strain activity in degradation of crude oil recalcitrant hydrocarbons with simultaneously lipopeptide production (Additional file 1: Fig. S6).

\section{Bioremediation of crude oil in the soil through various design treatments}

The current study revealed that lipopeptide produced by Bacillus subtilis SNW3 effectively removes crude oil from the soil. After applying different strategies, the residual crude oil content of each treatment showed different 

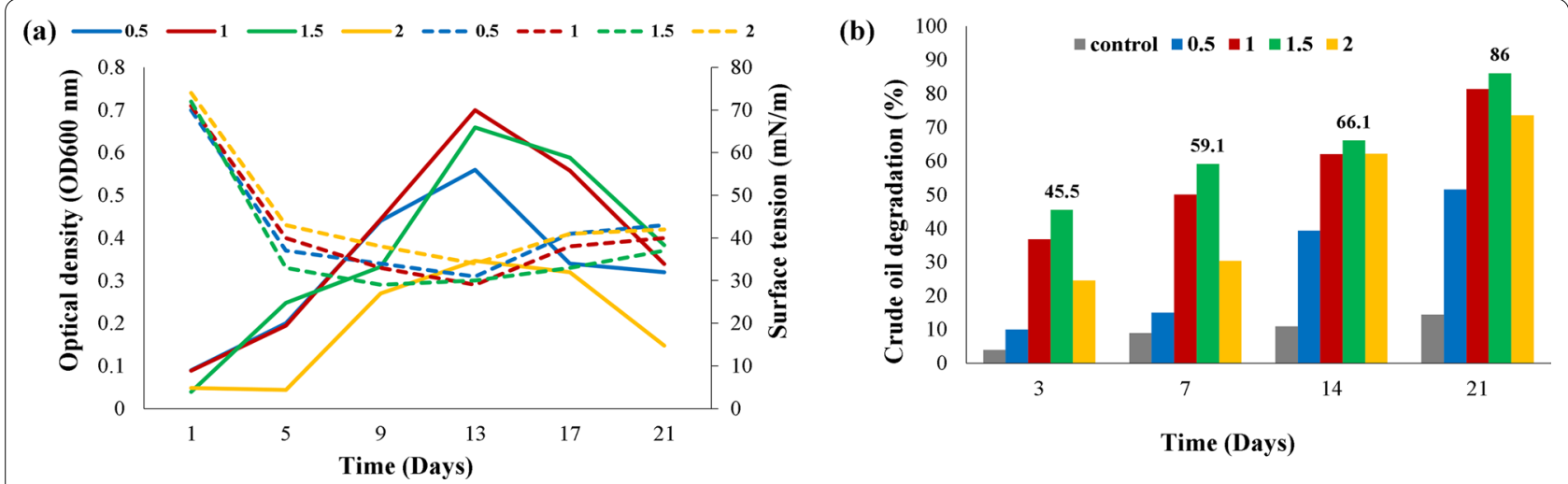

Fig. 6 The growth of a Bacillus subtilis SNW3 on crude oil and MSM with surface tension reduction values for 21 days, plane lines for OD600 and dotted lines for SFT, and $\mathbf{b}$ quantity of crude oil degraded (\%) by Bacillus subtilis SNW3 while growing on crude oil and MSM for 21 days

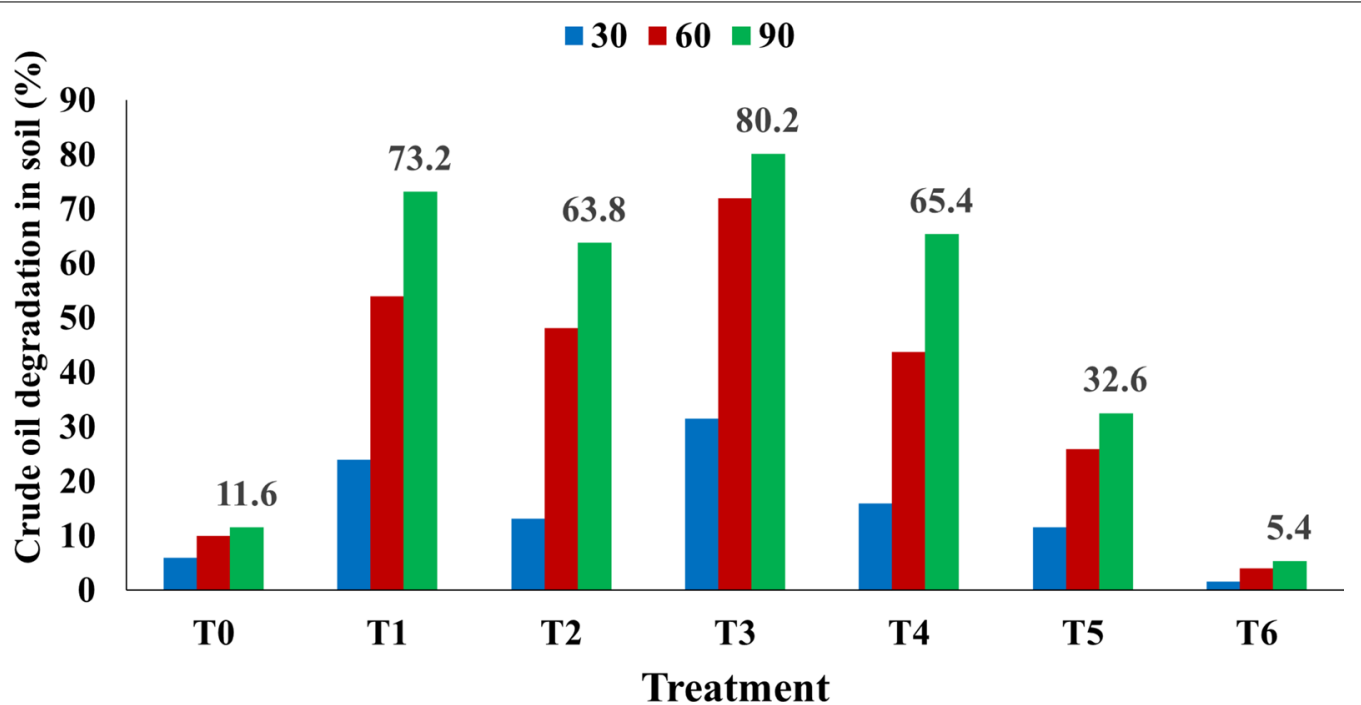

Fig. 7 The percent degradation of crude oil contaminated soil through various design treatments from T1-T6 for 90 days

extents of biodegradation. It was revealed that the combined strategy used in T3 gave measurable remediation of crude oil as compared to other treatments tested. There was a gradual increase in bioremediation capacity with time, maximum after 90 days. T3 treated with Bacillus subtilis SNW3 cultured microorganisms and CFS containing lipopeptides (80.2\%), show a significant difference from T0 control (11.6\%) with distilled water. The better bioremediation results $(73.2 \%)$ were obtained in $\mathrm{T} 1$ with the addition of lipopeptide than those obtained by $\mathrm{T} 2(63.8 \%)$ with the addition of biosurfactant producing Bacillus subtilis SNW3.

In the current study while making a comparison for bioremediation with chemical compounds it was observed that in T4, the addition of Tween 80 showed
65.4\% degradation lower than those treated with biosurfactants. The oil reduction results obtained for T5 with fertilizer showed (32.6\%) while the lowest degradation (5.4\%) was observed for T6 using autoclaved soil (Fig. 7).

\section{Discussion}

Biosurfactant production by using cost-effective substrates produced by Bacillus subtilis was previously studied by many researchers (Secato et al. 2016). An easy way to achieve cost-effective bioprocesses for biosurfactant production is by using a low-cost substrate. The use of waste frying oil as a sole source of carbon and energy for lipopeptide production by two Bacillus strains were previously reported by Md Badrul Hisham et al. (2019) that gave surface tension reduction values up to $36 \mathrm{mN} / \mathrm{m}$. 
Our results showed that Bacillus subtilis SNW3 growing on $2 \%$ waste frying oil gave $38 \mathrm{mN} / \mathrm{m}$ reduction value are in line with previous findings. De Lima et al. (2009) reported rhamnose production by Pseudomonas aeruginosa PACL strain cultivating on waste frying soybean oil with $100 \%$ emulsification index, surface tension reduction up to $26.0 \mathrm{mN} / \mathrm{m}$, and concentration of $3.3 \mathrm{~g} / \mathrm{L}$ while in the current study $56.3 \%$ emulsification was observed with $2 \%$ waste frying oil. Research conducted by AbdelMawgoud et al. (2008) investigated surfactin production in a cost-effective manner with the use of $16 \%$ molasses and other trace elements that produce a surfactin yield of $1.12 \mathrm{~g} / \mathrm{L}$. However, it is also stated in many studies that the presence of hydrophobic substrate is essential for the production of biosurfactants (Santos et al. 2016). According to literature different types of oils e.g., vegetable oils, waste cooking oil, glycerol, glucose, and diesel were screened out for biosurfactant production by fungal species M. circinelloides that showed $11.7 \mathrm{~cm}$ ODA with the use of waste cooking oil as carbon source. In another study conducted by Hasanizadeh et al. (2017) for biosurfactant production showed maximum biosurfactant production with the use of $8 \%(\mathrm{v} / \mathrm{v})$ waste cooking oil as a carbon source. Nitrogen is considered an important component of the medium used for biosurfactant production (Wu et al. 2008). In the literature, for higher biosurfactant yields number of nitrogenous compounds are listed that include yeast extract (Rodrigues et al. 2006a), beef extract, urea (Elazzazy et al. 2015), peptone, and meat extract (Gudiña et al. 2011). Urea was considered as a cheaper nitrogen source for significant lipopeptide production in comparison to sodium nitrate (Elazzazy et al. 2015; Farace et al. 2015; Ghribi and Ellouze-Chaabouni 2011). Yeast extract has been extensively selected in several studies (Marcelino et al. 2019). The yeast extract was used as a control medium as previously yeast extract was found as the most preferable substrate for significant biosurfactant production (Qazi et al. 2013). For instance, $L$. paracasei A20 preferred yeast extract as the significant medium for biosurfactant production followed by meat extract, while peptone was chartagorised as least important component of the medium (Gudiña et al. 2011).

It was reported previously that limitation in nitrogen concentration results in higher biosurfactant yield (Wu et al. 2019). The high carbon to nitrogen ratio $(\mathrm{C} / \mathrm{N})$ of the production medium (i.e., low level of nitrogen) limits bacterial growth, promoting cell metabolism for metabolites production (Nurfarahin et al. 2018). P. aeruginosa LBM10 in a culture medium containing soy bean oil as carbon source and $\mathrm{NaNO}_{3}$ as the source of nitrogen produce significant biosurfactant yield. Media composition with low nitrogen level produce $(1.42 \mathrm{~g} / \mathrm{L})$ as compared to higher nitrogen concentrations with biosurfactant yield of $0.94 \mathrm{~g} / \mathrm{L}$ (Prieto et al. 2008). The Kjeldahl or Dumas methods used for the evaluation of the crude protein in foods determine the total organic nitrogen of foods (Chandra-Hioe et al. 2018). The nitrogen content determination is crucial for the analysis of crude protein content. However, these provide rough assumptions as to the relative nitrogen and amino acid content differ between food proteins (Mæhre et al. 2018).

In the current study substrates were used in combination to increase biosurfactant production by reduce the price of culture media (Rufino et al. 2008). Slivinski et al. (2012) reported the use of okara obtained after processing ground soybeans as a substrate for surfactin by Bacillus pumilus UFPEDA 448. Zhu et al. (2013) also investigated the use of soybean flour as a substrate for surfactin production by Bacillus amyloliquefaciens XZ-173. To the best of our knowledge, for economical biosurfactant production, only a few studies are conducted by using soybean, but no single study is present that investigated the use of white beans powder as a substrate for low-cost production. The concentration of crude lipopeptide produced was (about $1.17 \mathrm{~g} / \mathrm{L}$ ), closed to other reported values for biosurfactant production using cost-effective substrates. The cost required for the preparation of one liter of optimized low-cost media in the current study is $0.078 \mathrm{EUR}$, which is just $0.8 \%$ of oneliter synthetic yeast extract media cost 10.5 EUR. Hence utilizing these cost-effective nonconventional media instead of synthetic yeast extract contribute to a $99 \%$ reduction in cost required for medium preparation.

It was reported by Samak et al. (2020) that $30^{\circ} \mathrm{C}$ is the optimum temperature for biosurfactant production that is in correspondence with results obtained in the current study. Our findings showed that no significant lipopeptide was produced at a static condition that might be due to lack of oxygenation (Santos et al. 2014). In a previous study conducted by Hemlata et al. (2015) for biosurfactant production by Stenotrophomonas maltophilia NBS-11 showed maximum production at $\mathrm{pH}$ 7. Urea and ammonium nitrate have been already used and reported in the literature as a very cost-effective nitrogen source for biosurfactant production by Candida spp. (Alwaely et al. 2019).The study conducted by Medeot et al. (2017) showed a high yield of biosurfactants $(1.7 \mathrm{mg} / \mathrm{mL})$ while using $\mathrm{NH}_{4} \mathrm{NO}_{3}$ and glucose as substrate for production by Bacillus amyloliquefaciens MEP218. In the same way, the combination of sucrose and $\mathrm{NH}_{4} \mathrm{NO}_{3}$ was reported by Fernandes et al. (2016), gave high yield of biosurfactant $(0.2 \mathrm{~g} / \mathrm{L})$ by Bacillus subtilis RI4914. Moreover, a study conducted for biosurfactant production showed optimum yield with $0.3 \%$ sodium nitrate by Pseudoxanthomonas 
sp. G3 (Purwasena et al. 2020). Current findings also showed maximum lipopeptide yield while using carbon nitrogen substrates in combination.

Surfactin acts as quorum-sensing molecule that provides a potential tool for the regulation of fermentation (Gupta et al. 2017), while carbon metabolism regulates the balance between the products and biomass. Biosurfactant production occurs frequently during a stationary stage of the cell growth after depletion of the nitrogen source (Onwosi and Odibo 2012). As a result of the current study, the final optimized carbon-nitrogen combination of the media significantly produced maximum biosurfactant with biomass and crude lipopeptide yield of 4.6 and $1.17 \mathrm{~g} / \mathrm{L}$ respectively. Recently, Phulpoto et al. (2020) reported glycerol and $\mathrm{NH}_{4} \mathrm{NO}_{3}$ as combined $\mathrm{C} / \mathrm{N}$ media for surfactin production that significantly produce biomass and crude biosurfactant yield of 4140 and $1255 \mathrm{mg} / \mathrm{L}$, respectively. Similarly, it was reported by Lu et al. (2016), that for fengycin production through Bacillus amyloliquefaciens fmb-60 biomass yield could be a significant factor. In Bacillus amyloliquefaciens BZ-6 (Liu et al. 2012), Bacillus amyloliquefaciens MEP218 (Medeot et al. 2017), Bacillus amyloliquefaciens fmb-60 (Lu et al. 2016) and Bacillus subtilis strains (Makkar et al. 2011), a direct correlation was reported between lipopeptide production and biomass yield. Primary characterization for biosurfactant produced by Bacillus subtilis SNW3 was carried out by using TLC using surfactin from sigma as standard. Here, our results for TLC of crude biosurfactant sample indicated lipopeptide nature of biosurfactant product through the presence of surfactin with an $\mathrm{Rf}$ value of 0.68 . These findings are consistent with other reported studies, where $\mathrm{Rf}$ value of 0.76 was observed by Ramyabharathi et al. (2018) for surfactin produced by Bacillus subtilis. Results obtained from previous findings also showed $\mathrm{Rf}$ values of $0.09,0.3$, and 0.75 for fengycin, iturin, and surfactin respectively using Bacillus subtilis UMAF6619, UMAF6614, UMAF8561, UMAF6639, and Bacillus amyloliquefaciens PPCB004 (Arrebola et al. 2010). FTIR results obtained were following TLC. The chemical structure of biosurfactant produced by Bacillus subtilis SNW3 was revealed by analyzing the crude extract using fourier transform infrared spectroscopy. FTIR analysis of crude biosurfactant produced by Bacillus subtilis SNW3 showed that it contains alcohols and carboxylic acids (lipids) and peptide moieties (proteins) that indicate lipopeptide nature of biosurfactant. A similar pattern of FTIR aliphatic and peptide moieties was reported for the presence of lipopeptides by Kiran et al. (2017). The observed pattern of IR spectrum was very similar to the spectrum obtained by de Faria et al. (2011) who reported the appearance of the stretch at $1721 \mathrm{~cm}^{-1}$ that indicates the presence of lactone carbonyl group.
Similar FTIR absorption spectra were reported in the literature for lipopeptide (Pereira et al. 2013).

Lipopeptide produced during the current study not only provides potential antibacterial activity but also renders bacteria more susceptible to the available antibiotics. Biosurfactants could be a suitable substitute for antimicrobial compounds and synthetic medicines and might be used as efficient therapeutic agents (Gudiña et al. 2013). The antimicrobial effect of biosurfactants is due to their potential to form pores inside cell membranes (Gudiña et al. 2010) this characteristic might increase the effectiveness of antibiotics. Sambanthamoorthy et al. (2014) revealed antimicrobial activities against $A$. baumannii, E. coli, and $S$. aureus at a concentration of $25-50 \mathrm{mg} /$ $\mathrm{mL}$. In our findings lipopeptide showed antimicrobial effect at a lower concentration of $10 \mathrm{mg} / \mathrm{mL}$ that showed more effectiveness of the lipopeptide product. These results are consistent with previous studies which suggest a synergistic effect of biosurfactant with antibiotics (Joshi-Navare and Prabhune 2013; Rivardo et al. 2011). The promising feature of natural antimicrobial peptides is their low toxicity and slow microbial resistance emergence rate as compared to the current antibiotics (Wang et al. 2019). Our findings suggested that lipopeptides could extend the clinical use of current antibiotics. Domhan et al. (2018) reported lipopeptides as novel antimicrobial agents against resistant microbial pathogens with favorable pharmacokinetics and enhanced antibacterial activity.

The critical micelle concentration (CMC) is the minimum biosurfactant concentration needed to achieve the lowest surface tension value at which micellar aggregates formation starts (Ma et al. 2016). CMC is an important characteristic of surface-active agents for evaluation of their interfacial activity (Zhou et al. 2019b). The CMC of crude lipopeptide produced by Bacillus subtilis SNW3 was found to be $\leq 0.58 \mathrm{mg} / \mathrm{mL}$, significant as compared to $2.7 \mathrm{mg} / \mathrm{mL}$ (Ghasemi et al. 2019). These results were also efficient as compared to commonly used synthetic surfactants sodium dodecyl sulfate (SDS) that attains CMC value at $2100 \mathrm{mg} / \mathrm{L}$ (Chen et al. 2006).

After biosurfactant production purification strategies account for near $60 \%$ of the total cost (Banat et al. 2010). Taking into consideration the industrial economic value, most the biosurfactants are required either in crude form or in form of broth preparations (Banat et al. 2010). Lipopeptide produced by Bacillus subtilis SNW3 exhibits excellent stability over an extensive range of $\mathrm{pH}(1-11)$, salinity $(1-8 \%)$, temperature $\left(20-121^{\circ} \mathrm{C}\right)$, and even after autoclaving. The decrease in stability of biosurfactants at acidic conditions might be due to the protonation of negative polar ends of surfactin molecules (Gogoi et al. 2016). A previous study conducted by Purwasena et al. 
(2019) showed biosurfactant stability with emulsification at a high temperature of $120{ }^{\circ} \mathrm{C}, \mathrm{pH}$ of $4-10$, and $\mathrm{NaCl}$ concentration of $10 \%(\mathrm{w} / \mathrm{v})$ that are in accordance with the current study. Moussa et al. (2013) showed biosurfactant stability at $20-120^{\circ} \mathrm{C}$ produced by Bacillus methylothrophicus and Rhodococcus equi strains. Different studies showed reduced biosurfactant stability under alkaline conditions. Several other studies have been reported about the stability of the biosurfactants at high salinity and temperature (Rodrigues et al. 2006b; Gudina et al. 2010). Significant stability of lipopeptide was found at high salinity and temperature and our findings were inconsistent with previous studies (Das and Kumar 2018; Hentati et al. 2019; Purwasena et al. 2019). Surfactin with excellent stability at wide range of temperature, $\mathrm{pH}$ and salinity widens its applicability in several industrial sectors e.g. food, pharmaceuticals, detergents, agricultural and bioremediation (Fenibo et al. 2019).

In the modern agricultural field use of bacterial biosurfactants plays an important role as they are ecofriendly and affordable (Hafeez et al. 2019; Muthusamy et al. 2008). Lipopeptides derived from bacterial strains are eco-friendly, less toxic, with more stability in harsh environments and highly biodegradable as compared to their synthetic counterparts (Lima et al. 2011). The genera Bacillus and Pseudomonas proved as e major producers of biosurfactant molecules (Hussain and Khan 2020; Zhou et al. 2019a). Lipopeptide produced by Bacillus subtilis SNW3 had a noticeable effect on seed germination and plant growth promotion that becomes more prominent with the increase in concentration. Our findings showed significant increase in seed germination of all four species tested most prominent for chilli and tomato. This increase in germination might be due to the reason that biosurfactant increases the permeability of seed coat to water that indirectly makes quicker the metabolic processes inside seeds (Kaur et al. 2017). The applied lipopeptide treatments augmented the dry biomass of all seeds tested, maximum for chilli pepper and lettuce. Similar results with an increase in plant biomass were observed by Liu et al. (2014). This increase in plant biomass might be due to the enhanced production of phytohormones and improved mineral solubilization in soil (Das and Kumar 2016). Almost all biosurfactant concentrations tested showed an immense effect on root elongation with better elongation in lettuce, pea and chilli. Enhanced plants root elongation could be due to decrease strength of wrapping tissues and seed coating that favors root development (da Silva et al. 2015). Another reason for the increase in root development by applying biosurfactants could be due to minimizing anaerobiosis conditions in the soil (Shukry et al. 2013). In current study significant effect was observed on plant growth promotion more prominent for chilli plants as compared to control. It was demonstrated by Cawoy et al. (2014) that surfactin by Bacillus isolates provokes concentration dependent induce systemic resistance (ISR). Surfactin act as a signaling molecule that provokes cannibalism and the formation of a matrix (López et al. 2009b). The improved plant development with biosurfactants ciould be incresae nutrients bioavailability and emulsification of hydrophobic compounds (Marchut-Mikolajczyk et al. 2018). Several researchers have reported the biosurfactant effect on seed germination, but to our knowledge, no previous study is available about current vegetable plants. Biopreparations are widely used nowadays for the enhanced seed quality and improved plant germination in contaminated soil (Mukherjee et al. 2006). However, some research gaps are still required to be filled about mechanisms followed by biosurfactants concerning enhanced growth and development of plants.

Lipopeptides are mostly applied in the biomedical field and only a few reports are present that showed the success story of lipopeptides in bioremediation of oilpolluted environments. In recent years, the use of biosurfactants for the treatment of oil-contaminated soil is increased (Karlapudi et al. 2018). Indigenous microbes that are normally present in oil-contaminated soil are mainly involved in the biodegradation of oil pollutants (Iwai et al. 2011; Lee et al. 2018). Through introducing biosurfactant-producing bacteria in the contaminated environment results in enhanced bioremediation utilizing solubilization, mobilization, and emulsification of hydrocarbons (Nievas et al. 2008). Crude oil is a complex mixture of aliphatic and aromatic hydrocarbons that inhibits the uptake of carbon sources required for metabolism and growth (Das and Chandran 2011). Many reports are present about the efficacy of biosurfactants produced by Bacillus species in oil recovery methods, bioremediation processes and industrial sectors (Greenwell et al. 2016; Ismail et al. 2013; Pereira et al. 2013).

Data obtained from our findings suggested Bacillus subtilis SNW3 as a potential bioremediation agent as compared to previously reported biodegradation studies (Sathishkumar et al. 2008). Bioremediation experiments conducted by Kumari et al. (2012) showed degradation percent of 49.5 and $60.6 \%$ for total petroleum hydrocarbons (TPH) by Rhodococcus sp. NJ2 and Pseudomonas sp. BP10 respectively. In our study more significant biodegradation of $86 \%$ was observed after 21 days. Al-Wasify and Hamed (2014) explained that P. aeruginosa reveal about $77.8 \%$ of maximum degradation after an incubation period of 28 days. Studies reported bioremediation of $49-54 \%$ for crude oil-polluted environments (Bordoloi and Konwar 2008) and more than 85\% for diesel oil-contaminated sand (Silva et al. 2010). 
Biosurfactant produced by S. marcescens UEO15 confirmed 59\% and 78\% degradation of kerosene and crude oil, in comparison of $25 \%$ and $10 \%$ with distilled water used as control (Elemba et al. 2010). Our study showed $86 \%$ efficacy in comparison to previous findings suggesting it as a more suitable bioremediation component in environmental sectors.

Tween 80 is suitable for remediation of contaminated soil because of its low cost as compared to other nonionic surfactants (Bautista et al. 2009), most successfully reported for polycyclic aromatic hydrocarbons PAHs (Gong et al. 2015). In the current study, T4 showed a $65.4 \%$ degradation rate that might be due to acidic conditions of soil that is unsuitable for microbial growth (Liu et al. 2010). Our findings suggested that treatments with biosurfactants enhanced the degradation rate employed it as a better bioremediation agent. Mishra and Singh (2012) reported that among degradative enzymes alkane hydroxylase produced by Rhodococcus sp. NJ2 and $P$. aeruginosa PSA5 result in degradation of n-hexadecane. Genes involved in the production of these degradative enzymes are reported in previous studies (de Gonzalo et al. 2016). Previous studies have reported the fertilizer as treatment to check the effects of NPK on the biodegradation of hydrocarbons (Pelletier et al. 2004). Nutrients especially phosphorus, nitrogen, and in some cases, iron are very essential ingredients for successful biodegradation of hydrocarbon pollutants (Adams et al. 2015).

Moreover, bioremediation technology is considered to be non-invasive and quite cost-effective (Azubuike et al. 2016; Kumar and Yadav 2018). Biodegradation through microorganisms signifies one of the principal mechanisms by which petroleum and other hydrocarbon pollutants can be removed from the environment (Al-Hawash et al. 2018; Das and Chandran 2011) and is cheaper than other remediation technologies (da Rocha Junior et al. 2019).

The current study demonstrated the use of cost-effective media for lipopeptide production by Bacillus subtilis SNW3. The possibility of utilizing waste frying oil in combination with white beans might be proved to be efficient to substitute yeast extract media and worthwhile for its industrial-scale production. The lipopeptides obtained exhibited potential emulsifying and surface tension reducing capabilities with strong stability at a wide range of $\mathrm{pH}$, temperature, and salinity. In addition, lipopeptide produced showed higher potential for seed germination and plant growth promotion of Capsicum annuum, Lactuca sativa, Solanum Lycopersicum, Pisum sativum, and removal of crude oil from contaminated soil, suggesting its potential applications in environmental and agriculture sectors.

\section{Abbreviations}

ATCC: American type culture collection; BCCM: Belgian coordinated collections of microorganisms; CMC: Critical micelle concentration; CMD: Critical micelle dilution; CFS: Cell-free supernatant; E24: Emulsification ability; FTIR: Fourier-transform infrared spectroscopy; $\mathrm{HCl}$ : Hydrochloric acid; HCN: Hydrogen cyanide; IAA: Indole acetic acid; ISR: Induced systemic resistance; Mol.: Molasses; MSM: Mineral salt medium; NaCl: Sodium chloride; NARC: National Agricultural Research Council; OD: Optical density; ODA: Oil displacement activity; P.P.P: Potato peels powder; PAHs: Polycyclic aromatic hydrocarbons; PGPR: Plant growth-promoting rhizobacteria; Rf: Retention factor; SDS: Sodium dodecyl sulfate; SFT: Surface tension; TLC: Thin-layer chromatography; TOC: Total organic carbon; TON: Total organic nitrogen; TPH: Total petroleum hydrocarbons; W.B.P. White beans powder; W.F.O: Waste frying oil; Y.E: Yeast extract.

\section{Supplementary Information}

The online version contains supplementary material available at https://doi. org/10.1186/s13568-021-01327-0.

Additional file 1: Figure S1. Effect of cultural conditions on lipopeptide production by Bacillus subtilis SNW3. (a) Temperature (b) inoculum (c) agitation and (d) $\mathrm{pH}$, error bars represent \pm standard deviation of triplicate values. Figure S2. Antibacterial activity of lipopeptide produced by Bacillus subtilis SNW3 against Escherichia coli and Salmonella typhi by using agar well diffusion assay. The error bars represent \pm standard deviation of triplicate values. Figure S3. Lipopeptide characterization by (a) critical micelles concentration (CMC) and (b) critical micelles dilution (CMD); produced by Bacillus subtilis SNW3 in relation to SFT measurement under optimized conditions. Figure S4. Effect of crude lipopeptide extract obtained from Bacillus subtilis SNW3 on (a) germination of seeds (b) dry biomass of plant (c) root length and (d) height of plants. The error bars represent \pm standard error of triplicate values. Figure S5. Results obtained for lipopeptide produced on optimized media (a) oil displacement activity in crude oil, (b) Emulsification activity (E24) up to 70\%) (c) screening of Bacillus subtilis SNW3 for growth and bioremediation with $1.5 \%$ crude oil in uninoculated control and sample after 21 days (d) extraction of crude oil media with hexane after 21 days from uninoculated control and sample through gravimetric analysis. Figure S6. Schematic diagram showing bacterial strain activity in degradation of crude oil recalcitrant hydrocarbons with simultaneously lipopeptide production. Table S1. Analysis of total organic carbon (TOC) and total organic nitrogen (TON) content of the substrate tested. Table S2. Statistical Mean (M), Std. Deviation (SD), Std. Error (SE) and $P$ value for relative seed germination, dry biomass, root length and plant height at four different concentrations of lipopeptide produced by Bacillus subtilis SNW3 used for four different plant species.

\section{Acknowledgements}

We acknowledge NARC (National Agriculture Research Council) Pakistan for providing seeds for the experiment.

\section{Authors' contributions}

$A U$ and SA: conception and study design; $A U$ and $A Z$ : carry out experimental work of study; AU, MPS and HW, AHN: testing and data analysis of the study; SA: supervision; $A U$ : draft the manuscript; $A U, M A Q, Z A M$, and SA: revised the manuscript. All authors read and approved the final manuscript.

\section{Funding}

No funding from externals is received for this research.

\section{Availability of data and materials}

The data used to support the findings of this study are available from the corresponding author upon request.

\section{Declarations}

Ethics approval and consent to participate

This article does not contain any human and animal studies performed by any of the authors. 


\section{Consent for publication}

Not applicable.

\section{Competing interests}

The authors declare that they have no competing interests.

\section{Author details}

'Department of Microbiology, Faculty of Biological Sciences, Quaid-i-Azam University, Islamabad 45320, Pakistan. ${ }^{2}$ Department of Microbiology, University of Balochistan, Quetta 87300, Pakistan. ${ }^{3}$ Department of Microbiology, Shah Abdul Latif University, Khairpur, Sindh 66111, Pakistan. ${ }^{4}$ Department of Psychology, Quaid-i-Azam University, Islamabad 45320, Pakistan.

Received: 22 September 2021 Accepted: 26 November 2021 Published online: 11 December 2021

\section{References}

Abdel-Mawgoud AM, Aboulwafa MM, Hassouna NA-H (2008) Optimization of surfactin production by Bacillus subtilis isolate BS5. Appl Biochem Biotechnol 150(3):305-325. https://doi.org/10.1007/s12010-008-8155-x

Abouseoud M, Yataghene A, Amrane A, Maachi R (2008) Biosurfactant production by free and alginate entrapped cells of Pseudomonas fluorescens. Ind Microbiol Biotechnol 35(11):1303-1308. https://doi.org/10.1007/ s10295-008-0411-0

Adams GO, Fufeyin PT, Okoro SE, Ehinomen I (2015) Bioremediation, biostimulation and bioaugmention: a review. Int J Environ Bioremediat Biodegrad 3(1):28-39. https://doi.org/10.12691/ijebb-3-1-5

Agamuthu P, Tan Y, Fauziah S (2013) Bioremediation of hydrocarbon contaminated soil using selected organic wastes. Procedia Environ $\mathrm{Sci}$ 18:694-702. https://doi.org/10.1016/j.proenv.2013.04.094

Akbari S, Abdurahman NH, Yunus RM, Fayaz F, Alara OR (2018) Biosurfactantsa new frontier for social and environmental safety: a mini review. Biotechnol Res Innov 2(1):81-90. https://doi.org/10.1016/j.biori.2018. 09.001

Alayande L, Mustapha K, Dabak J, Ubom G (2012) Comparison of nutritional values of brown and white beans in Jos North Local Government markets. Afr J Biotechnol 11(43):10135-10140. https://doi.org/10.1016/j. ejar.2018.06.001

Al-Hawash AB, Dragh MA, Li S, Alhujaily A, Abbood HA, Zhang X, Ma F (2018) Principles of microbial degradation of petroleum hydrocarbons in the environment. Egypt J Aquat Res 44(2):71-76. https://doi.org/10.1016/j. ejar.2018.06.001

Almansoory AF, Hasan HA, Abdullah SRS, Idris M, Anuar N, Al-Adiwish WM (2019) Biosurfactant produced by the hydrocarbon-degrading bacteria: characterization, activity and applications in removing TPH from contaminated soil. Environ Technol Innov 14:100347. https://doi.org/10. 1016/j.eti.2019.100347

Alwaely WA, Ghadban AK, Alrubayae IM (2019) Production and properties of biosurfactant from the local isolation of Candida spp. Drug Invent Today 12:948-953. https://doi.org/10.13140/RG.2.2.18357.32485

Al-Wasify RS, Hamed SR (2014) Bacterial biodegradation of crude oil using local isolates. Int J Bacteriol. https://doi.org/10.1155/2014/863272

Anandaraj B, Thivakaran P (2010) Isolation and production of biosurfactant producing organism from oil spilled soil. J Biosci Tech 1(3):120-126

Andrade Silva NR, Luna MA, Santiago AL, Franco LO, Silva GK, De Souza PM, Okada K, Albuquerque CD, Silva CA, Campos-Takaki GM (2014) Biosurfactant-and-bioemulsifier produced by a promising Cunninghamella echinulata isolated from caatinga soil in the northeast of Brazil. Int J Mol Sci 15(9):15377-15395. https://doi.org/10.3390/ijms150915377

Arrebola E, Jacobs R, Korsten L (2010) Iturin A is the principal inhibitor in the biocontrol activity of Bacillus amyloliquefaciens PPCB004 against postharvest fungal pathogens. J Appl Microbiol 108(2):386-395. https://doi. org/10.1111/j.1365-2672.2009.04438.x

Azubuike CC, Chikere CB, Okpokwasili GC (2016) Bioremediation techniquesclassification based on site of application: principles, advantages, limitations and prospects. World J Microbiol Biotechnol 32(11):1-18. https:// doi.org/10.1007/s11274-016-2137-x
Banani R, Youssef S, Bezzarga M, Abderrabba M (2015) Waste frying oil with high levels of free fatty acids as one of the prominent sources of biodiesel production. J Mater Environ Sci 6(4):1178-1185

Banat IM, Franzetti A, Gandolfi I, Bestetti G, Martinotti MG, Fracchia L, Smyth TJ, Marchant R (2010) Microbial biosurfactants production, applications and future potential. Appl Microbiol Biotechnol 87(2):427-444. https:// doi.org/10.1007/s00253-010-2589-0

Bautista LF, Sanz R, Molina MC, González N, Sánchez D (2009) Effect of different non-ionic surfactants on the biodegradation of PAHs by diverse aerobic bacteria. Int Biodeterior Biodegrad 63(7):913-922. https://doi.org/10. 1016/j.ibiod.2009.06.013

Benaissa A (2019) Plant growth promoting rhizobacteria a review. Alger J Environ Sci Technol 5(1):873-880

Bordoloi N, Konwar B (2008) Microbial surfactant-enhanced mineral oil recovery under laboratory conditions. Colloids Surf B Biointerfaces 63(1):73-82. https://doi.org/10.1016/j.colsurfb.2007.11.006

Campos J, Stamford T, Sarubbo L (2019) Characterization and application of a biosurfactant isolated from Candida utilis in salad dressings. Biodegradation 30(4):313-324. https://doi.org/10.1007/s10532-019-09877-8

Cawoy H, Mariutto M, Henry G, Fisher C, Vasilyeva N, Thonart P, Dommes J, Ongena M (2014) Plant defense stimulation by natural isolates of Bacillus depends on efficient surfactin production. Mol Plant-Microbe Interact 27(2):87-100. https://doi.org/10.1094/MPMI-09-13-0262-R

Chandra-Hioe M, Antony A, Arcot J (2018) Determination of protein in lupin using liquid chromatography coupled with organic carbon detector and organic nitrogen detector (LC-OCD-OND): validation of a new method. J Food Chem Nanotechnol 4(4):77-80

Chen J, Wang X-J, Hu J-D, Tao S (2006) Effect of surfactants on biodegradation of PAHs by white-rot fungi. Huan Jing Ke Xue = Huanjing Kexue 27(1):154-159

da Rocha Junior RB, Meira HM, Almeida DG, Rufino RD, Luna JM, Santos VA Sarubbo LA (2019) Application of a low-cost biosurfactant in heavy metal remediation processes. Biodegradation 30(4):215-233. https:// doi.org/10.1007/s10532-018-9833-1

da Silva VL, Lovaglio RB, Tozzi HH, Takaki M, Contiero J (2015) Rhamnolipids: a new application in seeds development. Med Biol Sci Res 1:100-106

D’aes J, Kieu NP, Léclère V, Tokarski C, Olorunleke FE, De Maeyer K, Jacques P, Höfte M, Ongena M (2014) To settle or to move? The interplay between two classes of cyclic lipopeptides in the biocontrol strain Pseudomonas CMR 12a. Environ Microbiol 16(7):2282-2300. https://doi.org/10.1111/ 1462-2920.12462

Das N, Chandran P (2011) Microbial degradation of petroleum hydrocarbon contaminants: an overview. Biotechnol Res Int. https://doi.org/10.4061/ 2011/941810

Das AJ, Kumar R (2016) Bioremediation of petroleum contaminated soil to combat toxicity on Withania somnifera through seed priming with biosurfactant producing plant growth promoting rhizobacteria. J Environ Manag 174:79-86. https://doi.org/10.1016/j.biortech.2018.09.047

Das AJ, Kumar R (2018) Utilization of agro-industrial waste for biosurfactant production under submerged fermentation and its application in oil recovery from sand matrix. Bioresour Technol 260:233-240. https://doi. org/10.1016/j.biortech.2018.03.093

Datta P, Tiwari P, Pandey LM (2018) Isolation and characterization of biosurfactant producing and oil degrading Bacillus subtilis MG495086 from formation water of Assam oil reservoir and its suitability for enhanced oil recovery. Bioresour Technol 270:439-448. https://doi.org/10.1016/j. biortech.2018.09.047

de Faria AF, Teodoro-Martinez DS, de Oliveira Barbosa GN, Vaz BG, Silva ÍS, Garcia JS, Tótola MR, Eberlin MN, Grossman M, Alves OL (2011) Production and structural characterization of surfactin (C14/Leu7) produced by Bacillus subtilis isolate LSFM-05 grown on raw glycerol from the biodiesel industry. Process Biochem 46(10):1951-1957. https://doi.org/ 10.1016/j.procbio.2011.07.001

de Gonzalo G, Colpa DI, Habib MH, Fraaije MW (2016) Bacterial enzymes involved in lignin degradation. J Biotechnol 236:110-119. https://doi. org/10.1016/j.jbiotec.2016.08.011

De Lima C, Ribeiro E, Servulo E, Resende M, Cardoso V (2009) Biosurfactant production by Pseudomonas aeruginosa grown in residual soybean oil. Appl Biochem Biotechnol 152(1):156-168. https://doi.org/10.1007/ s12010-008-8188-1 
Domhan C, Uhl P, Meinhardt A, Zimmermann S, Kleist C, Lindner T, Leotta K, Mier W, Wink M (2018) A novel tool against multiresistant bacterial pathogens: lipopeptide modification of the natural antimicrobial peptide ranalexin for enhanced antimicrobial activity and improved pharmacokinetics. Int J Antimicrob Agents 52(1):52-62. https://doi.org/ 10.1016/j.jjantimicag.2018.03.023

Ekprasert J, Kanakai S, Yosprasong S (2020) Improved biosurfactant production by Enterobacter cloacae B14, stability studies, and its antimicrobial activity. Pol J Microbiol 69(3):273. https://doi.org/10.33073/pjm-2020-030

Elazzazy AM, Abdelmoneim T, Almaghrabi O (2015) Isolation and characterization of biosurfactant production under extreme environmental conditions by alkali-halo-thermophilic bacteria from Saudi Arabia. Saudi J Biol Sci 22(4):466-475. https://doi.org/10.1016/j.sjbs.2014.11.018

Elemba OM, ljah UJJ, Chibunna M (2010) Isolation, characterization and MEOR ability of the biosurfactant produced from Serratia marcescens UEO15. Glob J Adv Res 2:962-974

Farace G, Fernandez O, Jacquens L, Coutte F, Krier F, Jacques P, Clément C, Barka EA, Jacquard C, Dorey S (2015) Cyclic lipopeptides from Bacillus subtilis activate distinct patterns of defence responses in grapevine. Mol Plant Pathol 16(2):177-187

Fenibo EO, ljoma GN, Selvarajan R, Chikere CB (2019) Microbial surfactants: the next generation multifunctional biomolecules for applications in the petroleum industry and its associated environmental remediation. Microorganisms 7(11):581. https://doi.org/10.3390/microorganisms7 110581

Ferhat S, Mnif S, Badis A, Eddouaouda K, Alouaoui R, Boucherit A, Mhiri N, Moulai-Mostefa N, Sayadi S (2011) Screening and preliminary characterization of biosurfactants produced by Ochrobactrum sp. 1C and Brevibacterium sp. 7G isolated from hydrocarbon-contaminated soils. Int Biodeterior Biodegrad 65(8):1182-1188. https://doi.org/10.1016/j. ibiod.2011.07.013

Fernandes P, Rodrigues E, Paiva F, Ayupe B, McInerney M, Tótola MJF (2016) Biosurfactant, solvents and polymer production by Bacillus subtilis RI4914 and their application for enhanced oil recovery. Fuel 180:551557. https://doi.org/10.1016/j.fuel.2016.04.080

Ganesh A, Lin J (2009) Diesel degradation and biosurfactant production by Gram-positive isolates. Afr J Biotechnol. https://doi.org/10.5897/AJB09. 811

Geetha S, Banat IM, Joshi SJ (2018) Biosurfactants: Production and potential applications in microbial enhanced oil recovery (MEOR). Biocatal Agric Biotechnol 14:23-32. https://doi.org/10.1016/j.bcab.2018.01.010

Ghasemi A, Moosavi-Nasab M, Setoodeh P. Mesbahi G, Yousefi G (2019) Biosurfactant production by lactic acid bacterium Pediococcus dextrinicus SHU1593 grown on different carbon sources: strain screening followed by product characterization. Sci Rep 9(1):1-12. https://doi.org/10.1038/ s41598-019-41589-0

Ghribi D, Ellouze-Chaabouni S (2011) Enhancement of Bacillus subtilis lipopeptide biosurfactants production through optimization of medium composition and adequate control of aeration. Biotechnol Res Int. https://doi.org/10.4061/2011/653654

Gogoi D, Bhagowati P, Gogoi P, Bordoloi NK, Rafay A, Dolui SK, Mukherjee AK (2016) Structural and physico-chemical characterization of a dirhamnolipid biosurfactant purified from Pseudomonas aeruginosa: application of crude biosurfactant in enhanced oil recovery. RSC Adv 6(74):70669-70681. https://doi.org/10.1039/C6RA11979D

Gong X, Xu X, Gong Z, Li X, Jia C, Guo M, Li H (2015) Remediation of PAHcontaminated soil at a gas manufacturing plant by a combined twophase partition system washing and microbial degradation process. Environ Sci Pollut Res 22(16):12001-12010. https://doi.org/10.1007/ s11356-015-4466-y

Goswami M, Deka S (2019) Biosurfactant production by a rhizosphere bacteria Bacillus altitudinis MS16 and its promising emulsification and antifungal activity. Colloids Surf B Biointerfaces 178:285-296. https://doi.org/10. 1016/j.colsurfb.2019.03.003

Greenwell M, Sarker M, Rahman PK (2016) Biosurfactant production and biodegradation of leather dust from tannery. Open Biotechnol J. https:// doi.org/10.2174/1874070701610010312

Gudina EJ, Teixeira JA, Rodrigues LR (2010) Isolation and functional characterization of a biosurfactant produced by Lactobacillus paracasei. Colloids Surf B Biointerfaces 76(1):298-304. https://doi.org/10.1016/j.colsurfb. 2009.11.008
Gudiña EJ, Rocha V, Teixeira J, Rodrigues L (2010) Antimicrobial and antiadhesive properties of a biosurfactant isolated from Lactobacillus paracasei ssp. paracasei A20. Lett Appl Microbiol 50(4):419-424. https://doi.org/ $10.1111 / j .1472-765 X .2010 .02818 . x$

Gudiña EJ, Teixeira JA, Rodrigues LR (2011) Biosurfactant-producing lactobacilli: screening, production profiles, and effect of medium composition. Appl Environ Soil Sci. https://doi.org/10.1155/2011/201254

Gudiña EJ, Rangarajan V, Sen R, Rodrigues LR (2013) Potential therapeutic applications of biosurfactants. Trends Pharmacol Sci 34(12):667-675. https://doi.org/10.1016/j.tips.2013.10.002

Guerfali M, Ayadi I, Sassi H-E, Belhassen A, Gargouri A, Belghith H (2020) Biodiesel-derived crude glycerol as alternative feedstock for single cell oil production by the oleaginous yeast Candida viswanathii Y-E4. Ind Crops Prod 145:112103. https://doi.org/10.1016/j.indcrop.2020.112103

Gupta A, Reizman IMB, Reisch CR, Prather KL (2017) Dynamic regulation of metabolic flux in engineered bacteria using a pathway-independent quorum-sensing circuit. Nat Biotechnol 35(3):273-279. https://doi.org/ $10.1038 / \mathrm{nbt} .3796$

Hafeez FY, Naureen Z, Sarwar A (2019) Surfactin: an emerging biocontrol tool for agriculture sustainability plant growth promoting rhizobacteria for agricultural sustainability. Springer, Singapore, pp 203-213. https://doi. org/10.1007/978-981-13-7553-8_10

Hasanizadeh P, Moghimi H, Hamedi J (2017) Biosurfactant production by Mucor circinelloides on waste frying oil and possible uses in crude oil remediation. Water Sci Technol 76(7):1706-1714. https://doi.org/10. 2166/wst.2017.338

Hemlata B, Selvin J, Tukaram K (2015) Optimization of iron chelating biosurfactant production by Stenotrophomonas maltophilia NBS-11. Biocatal Agric Biotechnol 4(2):135-143. https://doi.org/10.1016/j.bcab.2015.02. 002

Hentati D, Chebbi A, Hadrich F, Frikha I, Rabanal F, Sayadi S, Manresa A, Chamkha M (2019) Production, characterization and biotechnological potential of lipopeptide biosurfactants from a novel marine Bacillus stratosphericus strain FLU5. Ecotoxicol Environ Saf 167:441-449. https:// doi.org/10.1016/j.ecoenv.2018.10.036

Huang P, de-Bashan L, Crocker T, Kloepper JW, Bashan Y (2017) Evidence that fresh weight measurement is imprecise for reporting the effect of plant growth-promoting (rhizo) bacteria on growth promotion of crop plants. Biol Fertil Soils 53(2):199-208. https://doi.org/10.1007/ s00374-016-1160-2

Hussain T, Khan AA (2020) Bacillus subtilis HussainT-AMU and its antifungal activity against Potato Black scurf caused by Rhizoctonia solani on seed tubers. Biocatal Agric Biotechnol 23:101443. https://doi.org/10.1016/j. bcab.2019.101443

Ismail W, Al-Rowaihi IS, Al-Humam AA, Hamza RY, El Nayal AM, Bououdina M (2013) Characterization of a lipopeptide biosurfactant produced by a crude-oil-emulsifying Bacillus sp. I-15. Int Biodeterior Biodegrad 84:168-178. https://doi.org/10.1016/j.ibiod.2012.04.017

Iwai S, Johnson TA, Chai B, Hashsham SA, Tiedje JM (2011) Comparison of the specificities and efficacies of primers for aromatic dioxygenase gene analysis of environmental samples. Appl Environ Microbiol 77(11):35513557. https://doi.org/10.1128/AEM.00331-11

Jimoh AA, Lin J (2019) Biosurfactant: a new frontier for greener technology and environmental sustainability. Ecotoxicol Environ Saf 184:109607. https://doi.org/10.1016/j.ecoenv.2019.109607

Joshi-Navare K, Prabhune A (2013) A biosurfactant-sophorolipid acts in synergy with antibiotics to enhance their efficiency. BioMed Res Int. https://doi.org/10.1155/2013/512495

Joy S, Rahman PK, Sharma S (2017) Biosurfactant production and concomitant hydrocarbon degradation potentials of bacteria isolated from extreme and hydrocarbon contaminated environments. Chem Eng J 317:232241. https://doi.org/10.1016/j.cej.2017.02.054

Karlapudi AP, Venkateswarulu T, Tammineedi J, Kanumuri L, Ravuru BK, Ramu Dirisala V, Kodali VP (2018) Role of biosurfactants in bioremediation of oil pollution-a review. Petroleum 4(3):241-249. https://doi.org/10. 1016/j.pet/m.2018.03.007

Kaur N, Erickson TE, Ball AS, Ryan MH (2017) A review of germination and early growth as a proxy for plant fitness under petrogenic contamination-knowledge gaps and recommendations. Sci Total Environ 603:728-744. https://doi.org/10.1016/j.scitotenv.2017.02.179 
Kiran GS, Priyadharsini S, Sajayan A, Priyadharsini GB, Poulose N, Selvin J (2017) Production of lipopeptide biosurfactant by a marine Nesterenkonia sp. and its application in food industry. Front Microbiol 8:1138. https://doi.org/10.3389/fmicb.2017.01138

Krawczyńska M, Kolwzan B, Rybak J, Gediga K, Shcheglova NS (2012) The influence of biopreparation on seed germination and growth. Polish J Environ Stud 21(6):1697-1702

Kumar R, Yadav P (2018) Novel and cost-effective technologies for hydrocarbon bioremediation microbial action on hydrocarbons. Springer, Singapore, pp 543-565. https://doi.org/10.1007/978-981-13-1840-5_ 22

Kumari B, Singh SN, Singh DP (2012) Characterization of two biosurfactant producing strains in crude oil degradation. Process Biochem 47(12):2463-2471. https://doi.org/10.1016/j.procbio.2012.10.010

Ławniczak Ł, Marecik R, Chrzanowski $Ł$ (2013) Contributions of biosurfactants to natural or induced bioremediation. Appl Microbiol Biotechnol 97(6):2327-2339. https://doi.org/10.1007/s00253-013-4740-1

Lee DW, Lee H, Lee AH, Kwon B-O, Khim JS, Yim UH, Kim BS, Kim J-J (2018) Microbial community composition and PAHs removal potential of indigenous bacteria in oil contaminated sediment of Taean coast, Korea. Environ Pollut 234:503-512. https://doi.org/10.1016/j.envpol. 2017.11.097

Liang S, McDonald AG (2014) Chemical and thermal characterization of potato peel waste and its fermentation residue as potential resources for biofuel and bioproducts production. J Agric Food Chem 62(33):8421-8429. https://doi.org/10.1021/jf5019406

Lima TM, Procópio LC, Brandão FD, Leão BA, Tótola MR, Borges AC (2011) Evaluation of bacterial surfactant toxicity towards petroleum degrading microorganisms. Bioresour Technol 102(3):2957-2964. https://doi. org/10.1016/j.biortech.2010.09.109

Liu Z-F, Zeng G-M, Wang J, Zhong H, Ding Y, Yuan X-Z (2010) Effects of monorhamnolipid and Tween 80 on the degradation of phenol by Candida tropicalis. Process Biochem 45(5):805-809. https://doi.org/10. 1016/j.procbio.2010.01.014

Liu W, Wang X, Wu L, Chen M, Tu C, Luo Y, Christie P (2012) Isolation, identification and characterization of Bacillus amyloliquefaciens BZ-6, a bacterial isolate for enhancing oil recovery from oily sludge. Chemosphere 87(10):1105-1110. https://doi.org/10.1016/j.chemo sphere.2012.01.059

Liu W, Hou J, Wang Q, Ding L, Luo Y (2014) Isolation and characterization of plant growth-promoting rhizobacteria and their effects on phytoremediation of petroleum-contaminated saline-alkali soil. Chemosphere 117:303-308. https://doi.org/10.1016/j.chemosphere.2014.07.026

López D, Vlamakis H, Losick R, Kolter R (2009b) Paracrine signaling in a bacterium. Genes Dev 23(14):1631-1638. https://doi.org/10.1101/gad.18137 09

Lu H, Qian S, Muhammad U, Jiang X, Han J, Lu Z (2016) Effect of fructose on promoting fengycin biosynthesis in Bacillus amyloliquefaciens fmb-60. Appl Microbiol 121(6):1653-1664. https://doi.org/10.1111/jam.13291

Ma K-Y, Sun M-Y, Dong W, He C-Q, Chen F-L, Ma Y-L (2016) Effects of nutrition optimization strategy on rhamnolipid production in a Pseudomonas aeruginosa strain DN1 for bioremediation of crude oil. Biocatal Agric Biotechnol 6:144-151. https://doi.org/10.1016/j.bcab.2016.03.008

Mæhre HK, Dalheim L, Edvinsen GK, Elvevoll EO, Jensen I-J (2018) Protein determination—method matters. Foods 7(1):5. https://doi.org/10.3390/ foods 7010005

Makkar RS, Cameotra SS, Banat IM (2011) Advances in utilization of renewable substrates for biosurfactant production. AMB Express 1(1):1-19. https:// doi.org/10.1186/2191-0855-1-5

Malik Z, Ahmed S (2012) Degradation of petroleum hydrocarbons by oil field isolated bacterial consortium. Afr J Biotechnol 11(3):650-658. https:// doi.org/10.5897/AJB11.036

Marcelino P, Peres G, Terán-Hilares R, Pagnocca F, Rosa C, Lacerda T, dos Santos J, da Silva S (2019) Biosurfactants production by yeasts using sugarcane bagasse hemicellulosic hydrolysate as new sustainable alternative for lignocellulosic biorefineries. Ind Crops Prod 129:212-223. https://doi. org/10.1016/j.indcrop.2018.12.001

Marchut-Mikolajczyk O, Drożdżyński P, Pietrzyk D, Antczak T (2018) Biosurfactant production and hydrocarbon degradation activity of endophytic bacteria isolated from Chelidonium majus L. Microb Cell Factories 17(1):1-9. https://doi.org/10.1186/s12934-018-1017-5
Marchut-Mikołajczyk O, Drożdżyński P, Januszewicz B, Domański J, Wrześniewska-Tosik K (2019) Degradation of ozonized tire rubber by aniline_-degrading Candida methanosorbosa BP6 strain. J Hazard Mater 367:8-14. https://doi.org/10.1016/j.jhazmat.2018.12.045

Md Badrul Hisham NH, Ibrahim MF, Ramli N, Abd-Aziz S (2019) Production of biosurfactant produced from used cooking oil by Bacillus sp. HIP3 for heavy metals removal. Molecules 24(14):2617. https://doi.org/10.3390/ molecules 24142617

Medeot DB, Bertorello-Cuenca M, Liaudat JP, Alvarez F, Flores-Cáceres ML, Jofré E (2017) Improvement of biomass and cyclic lipopeptides production in Bacillus amyloliquefaciens MEP218 by modifying carbon and nitrogen sources and ratios of the culture media. Biol Control 115:119-128. https://doi.org/10.1016/j.biocontrol.2017.10.002

Mishra S, Singh S (2012) Microbial degradation of $n$-hexadecane in mineral salt medium as mediated by degradative enzymes. Bioresour Technol 111:148-154. https://doi.org/10.1016/j.biortech.2012.02.049

Moshtagh B, Hawboldt K, Zhang B (2018) Optimization of biosurfactant production by Bacillus subtilis N3-1P using the brewery waste as the carbon source. Environ Technol 40:3371-3380. https://doi.org/10.1080/ 09593330.2018.147350:

Moussa L, Azeiz A, Ahmed Z (2013) Identification and characterization of biosurfactants produced by Rodococcus equi and Bacillus methlyotrophicus. Biol Chem Environ Sci 8:341-358

Mukherjee S, Das P, Sen R (2006) Towards commercial production of microbial surfactants. Trends Biotechnol 24(11):509-515. https://doi.org/10. 1016/j.tibtech.2006.09.005

Munera-Echeverri JL, Martinsen V, Strand LT, Cornelissen G, Mulder J (2020) Effect of conservation farming and biochar addition on soil organic carbon quality, nitrogen mineralization, and crop productivity in a light textured Acrisol in the sub-humid tropics. PLoS ONE 15(2):e0228717. https://doi.org/10.1371/journal.pone.0228717

Muthusamy K, Gopalakrishnan S, Ravi TK, Sivachidambaram P (2008) Biosurfactants: properties, commercial production and application. Curr Sci 25:736-747

Nievas M, Commendatore M, Esteves J, Bucalá V (2008) Biodegradation pattern of hydrocarbons from a fuel oil-type complex residue by an emulsifierproducing microbial consortium. J Hazard Mater 154(1-3):96-104. https://doi.org/10.1016/j.jhazmat.2007.09.112

Nogueira L, Rodrigues ACF, Trídico CP, Fossa CE, de Almeida EA (2011) Oxidative stress in Nile tilapia (Oreochromis niloticus) and armored catfish (Pterygoplichthys anisitsi) exposed to diesel oil. Environ Monit Assess 180(1):243-255. https://doi.org/10.1007/s10661-010-1785-9

Novikov AA, Semenov AP, Monje-Galvan V, Kuryakov VN, Klauda JB, Anisimov MA (2017) Dual action of hydrotropes at the water/oil interface. J Phys Chem C 121(30):16423-16431. https://doi.org/10.1021/acs.jpcc.7b051 56

Nurfarahin AH, Mohamed MS, Phang LY (2018) Culture medium development for microbial-derived surfactants production—an overview. Molecules 23(5):1049. https://doi.org/10.3390/molecules23051049

Okop I, Okorie F, Obadimu C (2012) Quantitative evaluation of the spatial distribution and penetration of liquid hydrocarbons in petroleum spilled soil. Glob Adv Res J Environ Sci Toxicol 1(6):152-161

Ongena M, Jourdan E, Adam A, Paquot M, Brans A, Joris B, Arpigny JL, Thonart P (2007) Surfactin and fengycin lipopeptides of Bacillus subtilis as elicitors of induced systemic resistance in plants. Environ Microbiol 9(4):1084-1090. https://doi.org/10.1111/j.1462-2920.2006.01202.x

Onwosi CO, Odibo FJC (2012) Effects of carbon and nitrogen sources on rhamnolipid biosurfactant production by Pseudomonas nitroreducens isolated from soil. World J Microbiol Biotechnol 28(3):937-942. https:// doi.org/10.1007/s11274-011-0891-3

Palmonari A, Cavallini D, Sniffen C, Fernandes L, Holder P, Fagioli L, Fusaro I, Biagi G, Formigoni A, Mammi L (2020) Characterization of molasses chemical composition. J Dairy Sci 103(7):6244-6249. https://doi.org/10. 3168/jds.2019-17644

Patil S, Pendse A, Aruna K (2014) Studies on optimization of biosurfactant production by Pseudomonas aeruginosa F23 isolated from oil contaminated soil sample. Int J Curr Biotechnol 2(4):20-30

Patowary K, Patowary R, Kalita MC, Deka S (2017) Characterization of biosurfactant produced during degradation of hydrocarbons using crude oil as sole source of carbon. Front Microbiol 8:279. https://doi.org/10.3389/ fmicb.2017.00279 
Pawlik M, Cania B, Thijs S, Vangronsveld J, Piotrowska-Seget Z (2017) Hydrocarbon degradation potential and plant growth-promoting activity of culturable endophytic bacteria of Lotus corniculatus and Oenothera biennis from a long-term polluted site. Environ Sci Pollut Res 24(24):1964019652. https://doi.org/10.1007/s11356-017-9496-1

Pelletier E, Delille D, Delille B (2004) Crude oil bioremediation in sub-Antarctic intertidal sediments: chemistry and toxicity of oiled residues. Mar Environ Res 57(4):311-327. https://doi.org/10.1016/j.marenvres.2003.07.001

Pereira JF, Gudiña EJ, Costa R, Vitorino R, Teixeira JA, Coutinho JA, Rodrigues LR (2013) Optimization and characterization of biosurfactant production by Bacillus subtilis isolates towards microbial enhanced oil recovery applications. Fuel 111:259-268. https://doi.org/10.1016/j.fuel.2013.04. 040

Phulpoto IA, Yu Z, Hu B, Wang Y, Ndayisenga F, Li J, Liang H, Qazi MA (2020) Production and characterization of surfactin-like biosurfactant produced by novel strain Bacillus nealsonii S2MT and it's potential for oil contaminated soil remediation. Microb Cell Fact 19(1):1-12. https://doi. org/10.1186/s12934-020-01402-4

Prieto L, Michelon M, Burkert J, Kalil S, Burkert C (2008) The production of rhamnolipid by a Pseudomonas aeruginosa strain isolated from a southern coastal zone in Brazil. Chemosphere 71(9):1781-1785. https://doi. org/10.1016/j.chemosphere.2008.01.003

Purwasena IA, Astuti DI, Syukron M, Amaniyah M, Sugai Y (2019) Stability test of biosurfactant produced by Bacillus licheniformis DS1 using experimental design and its application for MEOR. J Pet Sci Eng 183:106383. https://doi.org/10.1016/j.petrol.2019.106383

Purwasena IA, Astuti DI, Utami SG (2020) Nitrogen optimization on rhamnolipid biosurfactant production from Pseudoxanthomonas sp. G3 and its preservation techniques. Sains Malays 49(9):2119-2127. https://doi. org/10.17576/jsm-2020-4909-10

Qazi M, Malik Z, Qureshi G, Hameed A, Ahmed S (2013) Yeast extract as the most preferable substrate for optimized biosurfactant production by $\mathrm{rhlB}$ gene positive Pseudomonas putida SOL-10 isolate. J Bioremediat Biodegrad 4(204):2. https://doi.org/10.4172/2155-6199.1000204

Ramyabharathi S, Meena KS, Rajendran L, Karthikeyan G, Jonathan E, Raguchander T (2018) Biocontrol of wilt-nematode complex infecting gerbera by Bacillus subtilis under protected cultivation. Egypt J Biol Pest Control 28(1):1-9. https://doi.org/10.1186/s41938-018-0027-2

Rastogi S, Tiwari S, Ratna S, Kumar R (2021) Utilization of agro-industrial waste for biosurfactant production under submerged fermentation and its synergistic application in biosorption of Pb2+. Bioresour Technol Rep 15:100706. https://doi.org/10.1016/j.biteb.2021.100706

Rivardo F, Martinotti MG, Turner RJ, Ceri H (2011) Synergistic effect of lipopeptide biosurfactant with antibiotics against Escherichia coli CFT073 biofilm. Int J Antimicrob Agents 37(4):324-331. https://doi.org/10. 1016/j.ijantimicag.2010.12.011

Rodrigues L, Teixeira J, Oliveira R, Van Der Mei HC (2006a) Response surface optimization of the medium components for the production of biosurfactants by probiotic bacteria. Process Biochem 41(1):1-10. https://doi. org/10.1016/J.PROCBIO.2005.01.030

Rodrigues LR, Teixeira JA, van der Mei HC, Oliveira R (2006b) Isolation and partial characterization of a biosurfactant produced by Streptococcus thermophilus A. Colloids Surf B Biointerfaces 53(1):105-112. https://doi. org/10.1016/j.colsurfb.2006.08.009

Rufino R, Sarubbo L, Campos-Takaki G (2007) Enhancement of stability of biosurfactant produced by Candida lipolytica using industrial residue as substrate. World J Microbiol Biotechnol 23(5):729-734. https://doi.org/ 10.1007/s11274-006-9278-2

Rufino RD, Sarubbo LA, Neto BB, Campos-Takaki GM (2008) Experimental design for the production of tensio-active agent by Candida lipolytica. J Ind Microbiol Biotechnol 35(8):907-914. https://doi.org/10.1007/ s10295-008-0364-3

Samak NA, Mahmoud T, Aboulrous A, Abdelhamid M, Xing J (2020) Enhanced biosurfactant production using developed fed-batch fermentation for effective heavy crude oil recovery. Energy Fuels 34(11):14560-14572. https://doi.org/10.1021/acs.energyfuels.0c02676

Sambanthamoorthy K, Feng X, Patel R, Patel S, Paranavitana C (2014) Antimicrobial and antibiofilm potential of biosurfactants isolated from lactobacilli against multi-drug-resistant pathogens. BMC Microbiol 14(1):1-9. https://doi.org/10.1186/1471-2180-14-197
Santos DK, Brandão YB, Rufino RD, Luna JM, Salgueiro AA, Santos VA, Sarubbo LA (2014) Optimization of cultural conditions for biosurfactant production from Candida lipolytica. Biocatal Agric Biotechnol 3(3):48-57. https://doi.org/10.1016/j.bcab.2014.02.004

Santos DKF, Rufino RD, Luna JM, Santos VA, Sarubbo LA (2016) Biosurfactants: multifunctional biomolecules of the 21st century. Int J Mol Sci 17(3):401. https://doi.org/10.3390/ijms17030401

Sathishkumar M, Binupriya AR, Baik SH, Yun SE (2008) Biodegradation of crude oil by individual bacterial strains and a mixed bacterial consortium isolated from hydrocarbon contaminated areas. Clean: Soil, Air, Water 1:92-96. https://doi.org/10.1002/clen.200700042

Secato J, Coelho D, Rosa N, Lima L, Tambourgi EB (2016) Biosurfactant production using Bacillus subtilis and industrial waste as substrate. Chem Eng Trans 49:103-108. https://doi.org/10.3303/CET1649018

Shaban SM, Abd-Elaal AA (2017) Studying the silver nanoparticles influence on thermodynamic behavior and antimicrobial activities of novel amide Gemini cationic surfactants. Mater Sci Eng C 76:871-885. https://doi. org/10.1016/j.msec.2017.03.185

Shukry W, Al-Hawas G, Al-Moaikal R, El-Bendary M (2013) Effect of petroleum crude oil on mineral nutrient elements, soil properties and bacterial biomass of the rhizosphere of jojoba. Br J Environ Clim Change 3(1):103-118. https://doi.org/10.9734/BJECC/2013/2492

Silva S, Farias C, Rufino R, Luna J, Sarubbo L (2010) Glycerol as substrate for the production of biosurfactant by Pseudomonas aeruginosa UCP0992. Colloids Surf B Biointerfaces 79(1):174-183. https://doi.org/10.1016/j. colsurfb.2010.03.050

Singh AK, Rautela R, Cameotra SS (2014) Substrate dependent in vitro antifungal activity of Bacillus sp. strain AR2. Microb Cell Factories 13(1):1-11. https://doi.org/10.1186/1475-2859-13-67

Slivinski CT, Mallmann E, de Araújo JM, Mitchell DA, Krieger N (2012) Production of surfactin by Bacillus pumilus UFPEDA 448 in solid-state fermentation using a medium based on okara with sugarcane bagasse as a bulking agent. Process Biochem 47(12):1848-1855. https://doi.org/10. 1016/j.procbio.2012.06.014

Toledo M, Siles J, Gutiérrez M, Martín M (2018) Monitoring of the composting process of different agroindustrial waste: influence of the operational variables on the odorous impact. Waste Manag 76:266-274. https://doi. org/10.1016/j.wasman.2018.03.042

Varjani SJ, Upasani VN (2016) Biodegradation of petroleum hydrocarbons by oleophilic strain of Pseudomonas aeruginosa NCIM 5514. Bioresour Technol 222:195-201. https://doi.org/10.1016/j.biortech.2016.10.006

Vea EB, Romeo D, Thomsen MJPC (2018) Biowaste valorisation in a future circular bioeconomy. Procedia Cirp 69:591-596. https://doi.org/10.1016/j. procir.2017.11.062

Wang J, Dou X, Song J, Lyu Y, Zhu X, Xu L, Li W, Shan A (2019) Antimicrobial peptides: promising alternatives in the post feeding antibiotic era. Med Res Rev 39(3):831-859. https://doi.org/10.1002/med.21542

Wayne P (2002) National committee for clinical laboratory standards. Perform Stand Antimicrob Disc Susceptibility Test 12:01-53

Wu J-Y, Yeh K-L, Lu W-B, Lin C-L, Chang J-S (2008) Rhamnolipid production with indigenous Pseudomonas aeruginosa EM1 isolated from oilcontaminated site. Bioresour Technol 99(5):1157-1164. https://doi.org/ 10.1016/j.biortech.2007.02.026

Wu L, Huang Z, Li X, Ma L, Gu Q, Wu H, Liu J, Borriss R, Wu Z, Gao X (2018) Stomatal closure and SA-, JA/ET-signaling pathways are essential for Bacillus amyloliquefaciens FZB42 to restrict leaf disease caused by Phytophthora nicotianae in Nicotiana benthamiana. Front Microbiol 9:847. https://doi.org/10.3389/fmicb.2018.00847

Wu T, Jiang J, He N, Jin M, Ma K, Long X (2019) High-performance production of biosurfactant rhamnolipid with nitrogen feeding. J Surfactants Deterg 22(2):395-402. https://doi.org/10.1002/jsde.12256

Yadav AK, Manna S, Pandiyan K, Singh A, Kumar M, Chakdar H, Kashyap PL, Srivastava AK (2016) Isolation and characterization of biosurfactant producing Bacillus sp. from diesel fuel-contaminated site. Microbiology 85(1):56-62. https://doi.org/10.1134/S0026261716010161

Yalçın HT, Ergin-Tepebașı G, Uyar E (2018) Isolation and molecular characterization of biosurfactant producing yeasts from the soil samples contaminated with petroleum derivatives. J Basic Microbiol 58(9):782-792. https://doi.org/10.1002/jobm.201800126

Yamamoto S, Shiraishi S, Suzuki S (2015) Are cyclic lipopeptides produced by Bacillus amyloliquefaciens S13-3 responsible for the plant defence 
response in strawberry against Colletotrichum gloeosporioides? Lett Appl Microbiol 60(4):379-386. https://doi.org/10.1111/lam.12382

Zhou D, Feng H, Schuelke T, De Santiago A, Zhang Q, Zhang J, Luo C, Wei L (2019a) Rhizosphere microbiomes from root knot nematode noninfested plants suppress nematode infection. Microb Ecol 78(2):470481. https://doi.org/10.1007/s00248-019-01319-5

Zhou J, Xue R, Liu S, Xu N, Xin F, Zhang W, Jiang M, Dong W (2019b) High di-rhamnolipid production using Pseudomonas aeruginosa KT1115, separation of mono/di-rhamnolipids, and evaluation of their properties. Front Bioeng Biotechnol 7:245. https://doi.org/10.3389/fbioe.2019. 00245

Zhu Z, Zhang F, Wei Z, Ran W, Shen Q (2013) The usage of rice straw as a major substrate for the production of surfactin by Bacillus amyloliquefaciens XZ-173 in solid-state fermentation. J Environ Manag 127:96-102. https://doi.org/10.1016/j.jenvman.2013.04.017

\section{Publisher's Note}

Springer Nature remains neutral with regard to jurisdictional claims in published maps and institutional affiliations.

\section{Submit your manuscript to a SpringerOpen ${ }^{\odot}$ journal and benefit from:}

- Convenient online submission

- Rigorous peer review

- Open access: articles freely available online

- High visibility within the field

- Retaining the copyright to your article

Submit your next manuscript at $\boldsymbol{\nabla}$ springeropen.com 